\title{
Photosynthetic Characteristics and Chloroplast Ultrastructure of Summer Maize Response to Different Nitrogen Supplies
}

\author{
Zheng Liu, Jia Gao, Fei Gao, Peng Liu, Bin Zhao and Jiwang Zhang* \\ State Key Laboratory of Crop Biology, College of Agronomy, Shandong Agricultural University, Tai'an, China
}

Maize (Zea mays L.) is the important crop over the world. Nitrogen $(\mathrm{N})$ as necessary element affects photosynthetic characteristics and grain yield of summer maize. In this study, N0 (0 kg N ha-1), N1 (129 kg N ha-1), N2 (185 kg N ha $\left.{ }^{-1}\right)$, and N3 (300 kg N ha-1) was conducted using hybrid 'ZhengDan958' at Dawenkou research field ( $36^{\circ} 11^{\prime} \mathrm{N}, 117^{\circ} 06^{\prime} \mathrm{E}, 178 \mathrm{~m}$ altitude) in the North China Plain to explore the effects of $\mathrm{N}$ rate on photosynthetic characteristics and chloroplast ultrastructure. Gas exchange parameters, chlorophyll fluorescence parameters, leaf area index (LAI), chlorophyll SPAD value, chloroplast ultrastructure, dry matter weight and grain yield were measured. At physiological maturity stage, dry matter weight and grain yield of N2 increased by 33-

OPEN ACCESS

Edited by: Abraham J. Escobar-Gutiérrez, Institut National de la Recherche

Agronomique (INRA), France

Reviewed by:

Jiasheng Wu,

Zhejiang A \& F University, China Cristina Nali,

Università degli Studi di Pisa, Italy

*Correspondence: Jiwang Zhang jwzhang@sdau.edu.cn

Specialty section: This article was submitted to Crop and Product Physiology, a section of the journal Frontiers in Plant Science

Received: 07 December 2017 Accepted: 13 April 2018 Published: 01 May 2018

Citation:

Liu Z, Gao J, Gao F, Liu P, Zhao B and Zhang J (2018) Photosynthetic

Characteristics and Chloroplast Ultrastructure of Summer Maize Response to Different Nitrogen Supplies. Front. Plant Sci. 9:576. doi: 10.3389/fp/s.2018.00576 52\% $(P \leq 0.05)$ and 6-32\% $(P \leq 0.05)$, respectively, compared with other treatments. During the growing from silking (R1) to milk (R3) stage, LAl of NO and N1 were 35-38\% $(P \leq 0.05)$ and $9-23 \%(P \leq 0.05)$ less than that of N2, respectively. Chlorophyll SPAD value of N0 and N1 were 13-22\% $(P \leq 0.05)$ and $5-11 \%(P \leq 0.05)$ lower than that of N2. There was no significant difference in LAl and chlorophyll SPAD value between $\mathrm{N} 2$ and N3 during the period from R1 to R3 $(P>0.05)$. The net photosynthetic rate $\left(P_{\mathrm{n}}\right)$, maximal quantum efficiency of PSII $\left(F_{\mathrm{v}} / F_{\mathrm{m}}\right)$ and quantum efficiency of PSII ( $\left.\Phi_{\mathrm{PS} I I}\right)$ were higher with the increase of $\mathrm{N}$ rate up to $\mathrm{N} 2(P \leq 0.05)$, and those of N3 were significantly less than N2 $(P \leq 0.05)$. In compared with $\mathrm{N} 2$, the chloroplast configuration of NO and N1 became elliptical, almost circular or irregular. The membrane of chloroplast and thylakoid resolved with growing stage, and the number of chloroplast per cell and lamellae per grana decreased under NO and N1 treatment $(P \leq 0.05)$. Under NO and $\mathrm{N} 1$ treatments, summer maize had more negative photosynthetic characteristics. The more number of osmium granule and vesicle and the larger gap between lamellae were shown in N3. Therefore, N2 treatment, $185 \mathrm{~kg} \mathrm{~N} \mathrm{ha}^{-1}$, is the appropriate application rate for grain yield, photosynthesis and chloroplast ultrastructure.

Keywords: summer maize, nitrogen rate, grain yield, photosynthetic characteristics, chloroplast ultrastructure

\section{INTRODUCTION}

Nitrogen $(\mathrm{N})$ is not only necessary element but also the limiting factor for grain yield of summer maize (Zea mays L.). However, the irrational $\mathrm{N}$ rate hinder production increase and result in environmental pollution (Zhang et al., 2016; Kong et al., 2017). In the North China Plain (NCP), local farmers' traditional $\mathrm{N}$ rate is $300 \mathrm{~kg} \mathrm{~N} \mathrm{ha}^{-1}$ to obtain higher grain yield, which is $62 \%$ more 
that the recommended $\mathrm{N}$ rate $\left(185 \mathrm{~kg} \mathrm{~N} \mathrm{ha}^{-1}\right)$, and the continued increases in $\mathrm{N}$ rate have not resulted in the commensurate increases in summer maize yield (Jin et al., 2012; Zhu et al., 2014; Liu et al., 2017).

Previous studies indicate that fertilizers, especially $\mathrm{N}$ fertilizer, make over $50 \%$ contribution in grain yield increase (Tilman et al., 2011; Fan et al., 2012). N managements promote maize growth and achieve high yield. The excessive $\mathrm{N}$ fertilizer may cause the reduction yield of summer maize whilst harming environment (Cui et al., 2010). The dry matter weight and grain yield are closely related. The basis of grain yield is high dry matter weight, especially accumulation of dry matter after anthesis (Plénet and Lemaire, 1999; Rajcan and Tollenaar, 1999). N application significantly increase dry matter weight, but excessive $\mathrm{N}$ rate would delay crops maturity and inhibit $\mathrm{N}$ translocation from vegetative organs to grain which is not conductive to crop production (Fang et al., 2006; Zhao et al., 2006). Leaf area index (LAI) is used to evaluate the development and structure of canopy. $\mathrm{N}$ deficiency reduce LAI since the leaves become slender, which result in light-leaking loss (Wilhelm et al., 2000; Bavec and Bavec, 2002). Excessive $\mathrm{N}$ rate make vegetative organs vigorously grow resulting in self-shade within the population, which have a negative effect on crop production. The chlorophyll SPAD value is used to determine the effect of $\mathrm{N}$ rate on leaf chlorophyll concentration since there is a non-linear relationship between them (Richardson et al., 2002). The chlorophyll SPAD value determine the $\mathrm{N}$ status of summer maize easily and quickly. $\mathrm{N}$ is the constituent of chlorophyll and $\mathrm{N}$ deficiency reduce leaf chlorophyll concentration. The parameters of leaf gas exchange and chlorophyll fluorescence reflect the carbon assimilation performance of the photosynthetic mechanism (Scheuermann et al., 1991; Nissanka et al., 1997; Fromm and Fei, 1998). The leaves suffer stomatal closure and related enzyme degradation under $\mathrm{N}$ deficiency, which decrease photosynthetic rate and PSII photochemical efficiency. The above negative performance result in significant decreases in grain yield. The changes in photosynthetic characteristics and chloroplast ultrastructure of field-grown summer maize would be responsible for the decreased yield with inaptitude $\mathrm{N}$ supply.

The morphology and ultrastructure of chloroplast directly affect photosynthesis, and have significant effects on dry matter weight and grain yield of summer maize (Slack et al., 1969; Chotewutmontri and Barkan, 2016; Shao et al., 2016). The intact chloroplast membrane is essential for the physiological function of chloroplasts; thylakoid membranes as the attachment site of chlorophyll are the biochemical reaction sites (Hall et al., 1972; Majeran et al., 2008). Previous studies showed that the concentration of $\mathrm{N}$ significantly affects the morphology and function of chloroplast (Harel et al., 1977; Tóth et al., 2002; Salesse-Smith et al., 2017). Adverse circumstances lead to chloroplast membrane and thylakoid membrane folds, thereby undermining its physiological function (Ristic and Cass, 1992). Maize, a C4 plant, generate C4 compounds catalyzed by phosphoenolpyruvate carboxylase (PEPC) in chloroplasts in mesophyll cells; these $\mathrm{C} 4$ compounds produce glucose through the Calvin cycle in the vascular sheath cells. Environmental stress impairs the morphology and function of chloroplasts, which weakens photosynthesis and decreases grain yields (Caers et al., 1985; Kratsch and Wise, 2000; Xu et al., 2006).

In comparison to the information on grain yield, dry matter weight, $\mathrm{N}$ use efficiency, and root growth and development responses (Jin et al., 2012; Zhu et al., 2014; Liu et al., 2017) only limited knowledge exists on the response of chloroplast ultrastructure to $\mathrm{N}$ rate under field conditions. Another interesting question is why does grain yield not increase continually with the increases in $\mathrm{N}$ rate. In order to answer above questions, this study was conducted in the field from 2015 to 2016 to evaluate the effects of $\mathrm{N}$ rate on photosynthetic characteristics and chloroplast ultrastructure of summer maize.

\section{MATERIALS AND METHODS}

\section{Experiment Site}

The experiment was conducted at Dawenkou research field $\left(36^{\circ} 11^{\prime} \mathrm{N}, 117^{\circ} 06^{\prime} \mathrm{E}, 178 \mathrm{~m}\right.$ a.s.l.) and State Key Laboratory of Crop Science in 2015 and 2016. This research field which is located in Shandong Province, China is characterized by brown loam soils and a temperate continental monsoon climate. Daily mean temperature and precipitation during the study period growing seasons are presented in Figure 1.

\section{Experiment Design}

Summer maize (Z. mays L. 'ZhengDan958'), the most popular hybrid in China, was planted at $7.5 \times 10^{4}$ seeds $\mathrm{ha}^{-1}$ on June 14th, 2015 and June 13th, 2016, and harvested on 1st October. The growing period of 2 years was listed in Table 1. Each plot consisted of 10 rows of maize planted $0.6 \mathrm{~m}$ apart and $40 \mathrm{~m}$ long. Four $\mathrm{N}$ rate $\left(0,129,185\right.$, and $\left.300 \mathrm{~kg} \mathrm{ha}^{-1}\right)$ were designated as four treatment (N0, N1, N2, and N3). The local N application rate was $300 \mathrm{~kg} \mathrm{ha}^{-1}$, whereas the recommended $\mathrm{N}$ rate based on previous research was $185 \mathrm{~kg} \mathrm{ha}^{-1}$. A rate of $129 \mathrm{~kg} \mathrm{ha}^{-1}$, $30 \%$ less than the recommendation, was chosen to provide $\mathrm{N}$ stress. $\mathrm{N}$ applications were split between pre-planting, six-leaf stage (V6), and silking stage (R1) (Table 2). Phosphorus (P) and potassium $(\mathrm{K})$ applied to each treatment were $56 \mathrm{~kg} \mathrm{P} \mathrm{ha}{ }^{-1}$ and $131 \mathrm{~kg} \mathrm{~K} \mathrm{ha-1}$ as calcium superphosphate and potassium chloride. $\mathrm{P}$ was applied $30 \mathrm{~kg} \mathrm{P} \mathrm{ha-1}$ before seeding and $26 \mathrm{~kg}$ $\mathrm{P} \mathrm{ha}^{-1}$ at V6. The $\mathrm{K}$ application was split-applied, 30, 71, and $30 \mathrm{~kg} \mathrm{~K} \mathrm{ha}{ }^{-1}$ before seeding, at V6, and at R1. All fertilizer was applied by furrow between rows. Irrigation $(80 \mathrm{~mm})$ was applied at seeding only. In all experimental fields, weeds were well controlled by intermixture of nicosulfuron and atrazine. The straw derived from previous crops, winter wheat, was returned by rotary tillage before planting summer maize. The $50 \%$ phoxim emulsion $\left(3 \mathrm{~kg} \mathrm{ha}^{-1}\right)$ was applied by furrow between rows while seeding. No obvious water or pest stress occurred during the growing season.

\section{Grain Yield and Its Components}

At R6, 30 ears were obtained from the center three rows of each plot to determine kernel number per ear and thousand-kernel weight. Ears ha ${ }^{-1}$ was determined by counting plants per plot. All the kernels were air-dried to investigate yield, and grain yield 


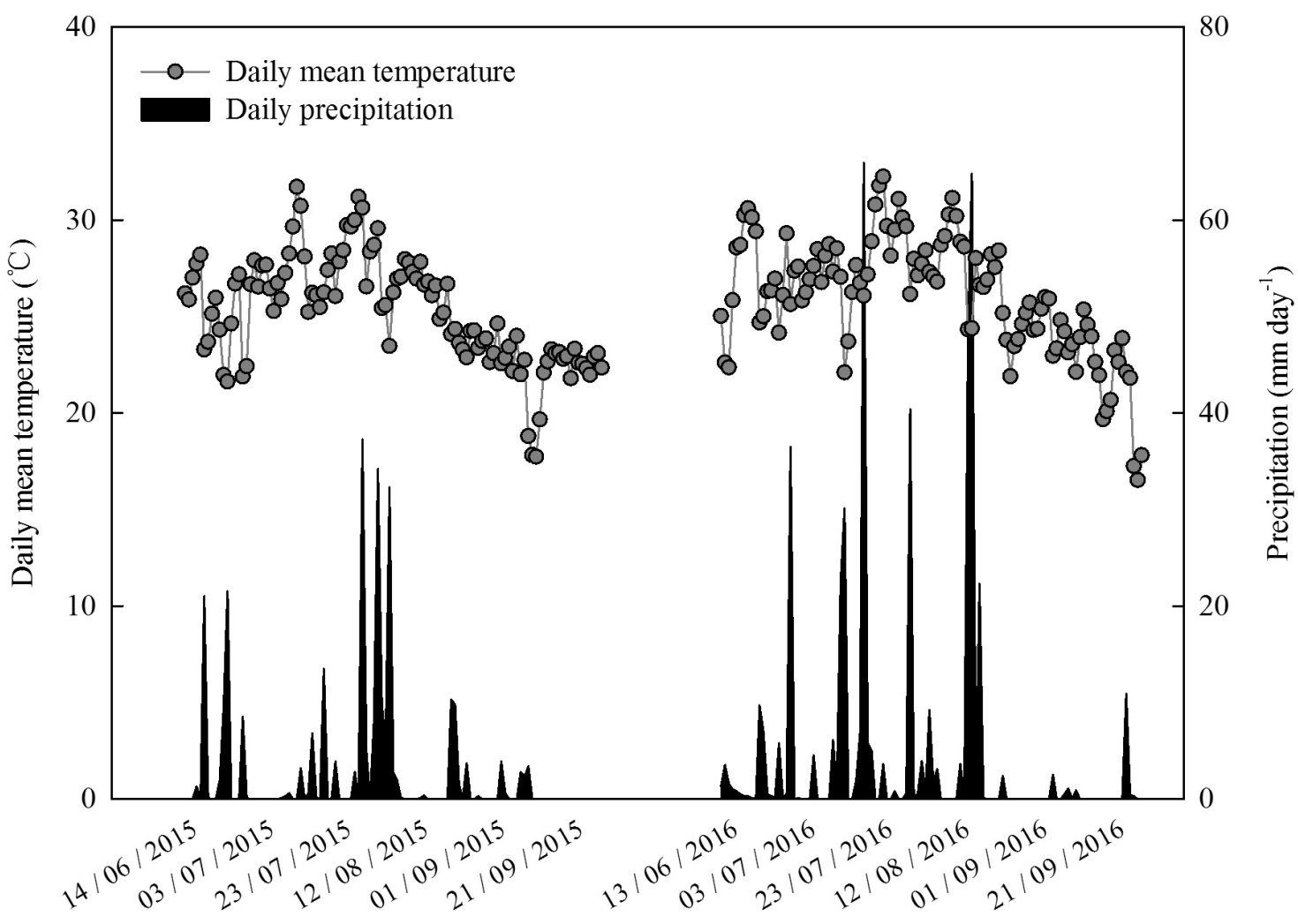

Date $(\mathrm{dd} / \mathrm{mm} / \mathrm{yyyy})$

FIGURE 1 | Daily mean air temperature and precipitation during the maize growing seasons in 2015 and 2016 at Dawenkou research field $\left(36^{\circ} 11^{\prime} \mathrm{N}, 117^{\circ} 06^{\prime} \mathrm{E}, 178\right.$ m a.s.l.).

TABLE 1 | Growing period of summer maize in 2015 and 2016.

\begin{tabular}{|c|c|c|c|c|c|c|}
\hline Year & Seeding & V6 & V12 & R1 & R3 & R6 \\
\hline 2015 & 15th June & 13th July & 1st August & 13th August & 11th September & 1st October \\
\hline 2016 & 13th June & 11th July & 31st July & 10th August & 10th September & 1st October \\
\hline
\end{tabular}

The criterion for growth stage is that more than 50\% plants of population reached this stage. V6: six-leaf stage; V12: twelve-leaf stage; R1: silking stage; R3: milk stage; R6: physiological maturity stage.

was expressed at 14\% moisture (Gb/T 29890-2013, 2013). Grain yield was calculated as: Grain yield $\left(\mathrm{Mg} \mathrm{ha}^{-1}\right.$, at about $140 \mathrm{~g}$ $\mathrm{kg}^{-1}$ moisture $)=$ ear number per hectare $\times$ kernel number per ear $\times$ thousand kernel weight $/ 10^{9}$.

TABLE 2 | Nitrogen timing (V6: six-leaf stage; R1: silking stage) and application rate $\left(\mathrm{kg} \mathrm{ha}^{-1}\right)$ for different $\mathrm{N}$ treatments applied to summer maize.

\begin{tabular}{lccc}
\hline Treatment & Before seeding & V6 & R1 \\
\hline N0 & - & - & - \\
N1 & 21 & 63 & 45 \\
N2 & 30 & 90 & 65 \\
N3 & 50 & 145 & 105
\end{tabular}

Nitrogen applied to maize are $0 \mathrm{~kg} \mathrm{~N} \mathrm{ha}^{-1}(\mathrm{NO}), 129 \mathrm{~N} \mathrm{ha}^{-1}(\mathrm{N1}), 185 \mathrm{~kg} \mathrm{~N} \mathrm{ha}^{-1}$ (N2), and $300 \mathrm{~kg} \mathrm{Nha}^{-1}$ (N3).

\section{Leaf Area Index (LAI)}

Fifteen representative plants were marked in each plot at V6, 12 leaf stage (V12), R1, R3 and physiological maturity stage (R6) to measure maximum width $\left(\lambda_{\mathrm{m}}\right)$, total length $\left(L_{t}\right)$, width at ligule level $\left(\lambda_{0}\right)$ and distance from ligule to the point of maximum width $\left(L_{\mathrm{x}}\right)$ of each leaf for the individual tagged plants. The leaf area was calculated according to the method of Combe (2005), and leaf area index (LAI) is the leaf area of the unit land area.

\section{Chlorophyll SPAD Value}

Ten plants were randomly selected from each plot at V6, V12, R1, R3, and R6 from 10:00 AM to 1:00 PM. SPAD value was measured non-destructively with the portable SPAD-502 Chlorophyll Meter (Minolta Camera Co., Japan) from the functional leaf of each plant, and then averaged. During measurements with the SPAD-502, the sensor head was shaded with the operator's 
own body as recommended by the manufacturer to avoid direct sunlight from reaching the instrument.

\section{Dry Matter Weight}

Five plant samples were obtained from the center of each plot at V6, V12, R1, R3, and R6, and separated into grain and straw at R6. The samples were dried in an oven (DHG-9420A; Bilon Instruments Co. Ltd., Shanghai, China) at $85 \pm 5^{\circ} \mathrm{C}$, after heating at $105^{\circ} \mathrm{C}$ for $30 \mathrm{~min}$, to a constant weight and the dry weight was then measured.

\section{Leaf Gas Exchange Parameters and Chlorophyll Fluorescence Parameters}

At V6, R1 and milk stage (R3), the photosynthetic rate $\left(P_{\mathrm{n}}\right)$, transpiration rate $\left(T_{\mathrm{r}}\right)$, stomatal conductance $\left(G_{\mathrm{s}}\right)$ and intercellular $\mathrm{CO}_{2}$ concentration $\left(C_{\mathrm{i}}\right)$ of the functional leaf (last ligulated leaf at V6, and ear leaf at R1 and R3) (Escobar-Gutiérrez and Combe, 2012) were measured using a portable infrared gas analyzer (CIRAS II, PP System, Hansatech, United Kingdom) from 10:00 AM to 1:00 PM. Measurement conditions were kept consistent: LED light source and the PAR was $1600 \mu \mathrm{mol}$ $\mathrm{m}^{-2}$. $\mathrm{CO}_{2}$ concentration was maintained at a constant level of $360 \mu \mathrm{mol} \mathrm{mol}^{-1}$ using a $\mathrm{CO}_{2}$ injector with a high-pressure liquid $\mathrm{CO}_{2}$ cartridge source (Wang et al., 2009; Qi et al., 2012).

Chlorophyll fluorescence was measured with a FMS-II plus modulated fluorometer (Hansatech, United Kingdom) on the same leaves as used for gas exchange measurements from 10:00 AM to 1:00 PM. Minimal fluorescence $\left(F_{0}\right)$ was measured under a weak pulse of modulating light over a $0.8 \mathrm{~s}$ period, and maximal fluorescence $\left(F_{\mathrm{m}}\right)$ was induced by a saturating pulse of light $\left(8000 \mu \mathrm{mol} \mathrm{m} \mathrm{m}^{-2} \mathrm{~s}^{-1}\right)$ applied over $0.8 \mathrm{~s}$. The maximal quantum efficiency of PSII was determined as $F_{\mathrm{v}} / F_{\mathrm{m}}$, where $F_{\mathrm{v}}$ is the difference between $F_{0}$ and $F_{\mathrm{m}}$. An actinic light source (600 $\mu \mathrm{mol} \mathrm{m} \mathrm{m}^{-2} \mathrm{~s}^{-1}$ ) was then applied to achieve steady-state photosynthesis and to obtain $F_{\mathrm{s}}$ (steady-state fluorescence yield), after which a second saturation pulse was applied for $0.7 \mathrm{~s}$ to obtain $F_{\mathrm{m}}$ ' (light-adapted maximum fluorescence). Fluorescence parameters were calculated by FMS-II, based on the dark-adapted for $20 \mathrm{~min}$ and light-adapted fluorescence measurements (Wang and Jin, 2005; Wang et al., 2009). The quantum efficiency of PSII ( $\left.\Phi_{\text {PSII }}\right)$ was calculated as $\left(F_{\mathrm{m}}{ }^{\prime}-F_{\mathrm{s}}\right) / F_{\mathrm{m}}{ }^{\prime}$ (Genty et al., 1989).

\section{Transmission Electron Microscope (TEM) Sample Preparation and Observation}

In 2016, the illuminated sides of five ear leaves were obtained from the center of each plot at V6, R1, and R3 stages. A square section of a leaf $(0.5 \mathrm{~cm} \times 0.5 \mathrm{~cm})$ near the center vein of each leaf was removed with a blade. After fixation with $2.5 \%$ glutaraldehyde for $4 \mathrm{~h}$, leaf cells were post-fixed with osmic acid at $4^{\circ} \mathrm{C}$ for $4 \mathrm{~h}$ and then dehydrated with ethanol. When embedded in spurr resin at $70^{\circ} \mathrm{C}$ for $8 \mathrm{~h}$, thin sections were cut from leaf samples with an LKB-V ultra-microtome (Pharmacia LKB Co., Sweden) and placed upon 250 mesh grids. Samples were double stained using stem uranyl acetate and lead citrate and then observed and randomly photographed using a Hitachi-600 transmission electron microscope (Hitachi Ltd., Japan).

\section{Statistical Analysis}

Data of chloroplast ultrastructure were tested by Shapiro-Wilk and Levene tests and then analyzed by one-way analysis of variance (one-way ANOVA) procedure using SPSS 17.0 software (SPSS Inc., United States) with $P \leq 0.05$ considered significant. Two-way repeated measures analysis of variance (two-way repeated ANOVA) with Bonferroni was used compare other data after Shapiro-Wilk and Mauchly's tests. Treatments were compared with Duncan's multiple range test $(P \leq 0.05)$.

\section{RESULTS}

\section{Grain Yield and Its Components}

As shown in Table 3, $\mathrm{N}$ rate had extremely significant effects on grain yield and its components of summer maize $(P \leq 0.01)$. Grain yield increased with the increase of $\mathrm{N}$ rate up to $\mathrm{N} 2$, and no greater yield was obtained in N3. Compared with N0, grain yield of N1 and N2 increased by $22 \%(P \leq 0.05)$ and $32 \%(P \leq 0.05)$ in 2015 , by $16 \%(P \leq 0.05)$ and $29 \%(P \leq 0.05)$ in 2016 , respectively. In $2015, \mathrm{~N} 2$ and N3 did not differ $(P>0.05)$. In 2016, N3 was $6 \%(P \leq 0.05)$ less than N2. Ears per hectare, kernels per ear and thousand-kernel weight (TKW) of N0 were the lowest $(P \leq 0.05)$. There was no significant difference in ears per hectare between N2 and N3 $(P>0.05)$. The kernels per ear of N0 was significantly lower than others $(P \leq 0.05)$ and no significant difference was obtained among N1, N2, and N3 $(P>0.05)$. TKW of N2 increased by $7 \%(P \leq 0.05)$ and $4 \%(P \leq 0.05)$ in 2015 , by $10 \%(P \leq 0.05)$ and $9 \%(P \leq 0.05)$ in 2016, respectively, compared with N0 and N1. In 2015, TKW between N2 and N3 did not differ $(P>0.05)$ but that of N3 decreased by $5 \%(P \leq 0.05)$ compared with N2 in 2016.

TABLE 3 | Grain yield and yield components of summer maize as affected by $\mathrm{N}$ rate.

\begin{tabular}{|c|c|c|c|c|c|}
\hline Year & Treatment & $\begin{array}{l}\text { Grain yield } \\
\left(\mathrm{Mg} \mathrm{ha}^{-1}\right)\end{array}$ & $\begin{array}{c}\text { Ears } \\
\text { (No. } 10^{4} \mathrm{ha}^{-1} \text { ) }\end{array}$ & $\begin{array}{c}\text { Kernels } \\
\text { (No. ear-1) }\end{array}$ & $\begin{array}{l}\text { TKW } \\
\text { (g) }\end{array}$ \\
\hline \multirow[t]{4}{*}{2015} & NO & $10.1^{c}$ & $6.7^{\mathrm{c}}$ & $490.1^{b}$ & $307.9^{c}$ \\
\hline & N1 & $12.3^{b}$ & $7.0^{\mathrm{b}}$ & $553.2^{\mathrm{a}}$ & $318.0^{\mathrm{b}}$ \\
\hline & N2 & $13.3^{\mathrm{a}}$ & $7.4^{\mathrm{a}}$ & $544.9^{a}$ & $330.9^{a}$ \\
\hline & N3 & $13.4^{\mathrm{a}}$ & $7.4^{\mathrm{a}}$ & $552.1^{\mathrm{a}}$ & $327.0^{a}$ \\
\hline \multirow[t]{4}{*}{2016} & No & $11.2^{d}$ & $6.9^{b}$ & $519.9^{b}$ & $312.1^{c}$ \\
\hline & $\mathrm{N} 1$ & $13.0^{c}$ & $7.4^{\mathrm{a}}$ & $554.8^{\mathrm{a}}$ & $316.0^{c}$ \\
\hline & N2 & $14.4^{\mathrm{a}}$ & $7.4^{\mathrm{a}}$ & $567.1^{a}$ & $343.1^{\mathrm{a}}$ \\
\hline & N3 & $13.5^{\mathrm{b}}$ & $7.4^{\mathrm{a}}$ & $559.9^{a}$ & $327.0^{\mathrm{b}}$ \\
\hline Shapiro-Wilk test & & NS & NS & NS & NS \\
\hline Mauchly's test & & NS & NS & NS & NS \\
\hline \multicolumn{6}{|c|}{ Two-way repeated ANOVA } \\
\hline Treatment (T) & & ** & $* *$ & $* *$ & $* *$ \\
\hline Year $(Y)$ & & $*$ & NS & $*$ & $*$ \\
\hline$T \times Y$ & & NS & NS & NS & NS \\
\hline
\end{tabular}

TKW, thousand-kernel weight. Values followed by a different small letter in the same year are significantly different at $P \leq 0.05$ with Duncan's multiple range test. NS, not significant, $P>0.05 . *, * *$ significant at the 0.05 and 0.01 probability level, respectively. Nitrogen applied to maize are $0 \mathrm{~kg} \mathrm{~N} \mathrm{ha}^{-1}$ (N0), $129 \mathrm{~N} \mathrm{ha}^{-1}$ (N1), $185 \mathrm{~kg} \mathrm{Nha}^{-1}$ (N2), and $300 \mathrm{~kg} \mathrm{~N} \mathrm{ha}^{-1}$ (N3). 


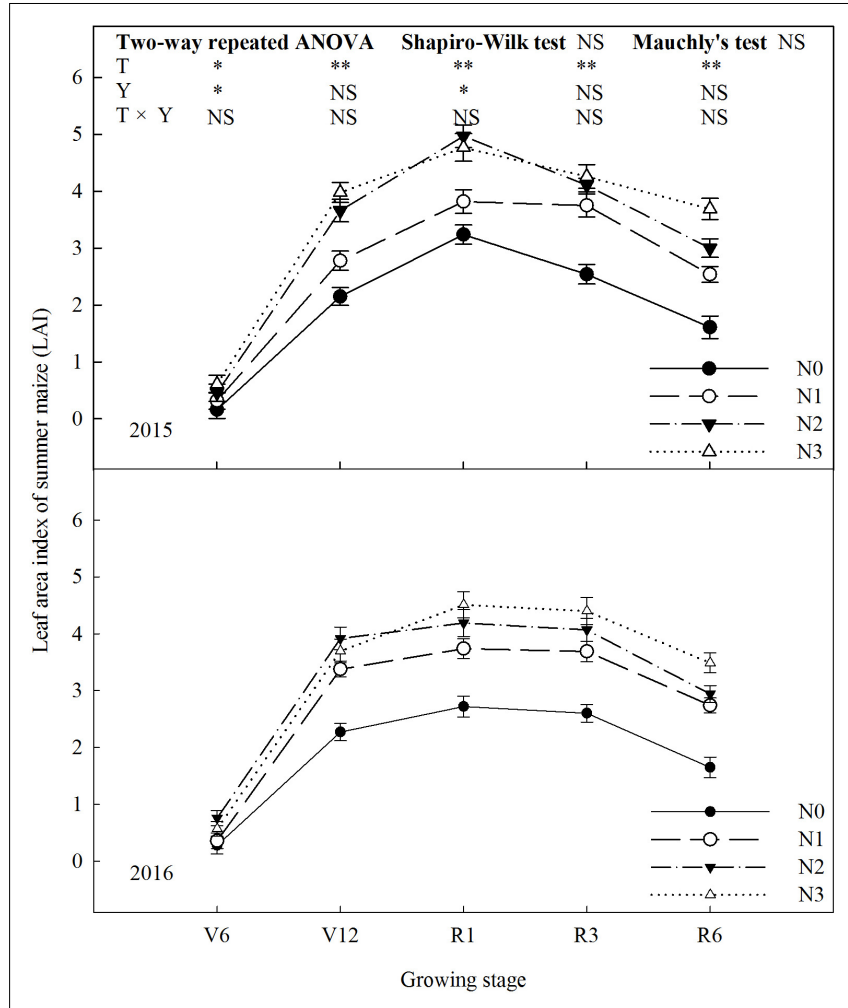

FIGURE 2 | Effect of nitrogen rate on leaf area index (LAl) of summer maize during growth stages in 2015 and 2016. V6: six-leaf stage, V12: twelve-leaf stage, R1: silking stage, R3: milk stage, R6: physiological maturity stage. Nitrogen applied to maize are $0 \mathrm{~kg} \mathrm{~N} \mathrm{ha}^{-1}$ (N0), $129 \mathrm{~N} \mathrm{ha}^{-1}$ (N1), $185 \mathrm{~kg} \mathrm{~N}$ $\mathrm{ha}^{-1}$ (N2), and $300 \mathrm{~kg} \mathrm{~N}^{-1}$ (N3). Error bars are given as SD. NS, not significant, $P>0.05$. ${ }^{*}, *$ Significant at the 0.05 and 0.01 probability level, respectively.

\section{Leaf Area Index (LAl)}

$\mathrm{N}$ fertilization promoted LAI of summer maize (Figure 2). LAI of N2 was significantly higher than that of N0 and N1 during the growing season $(P \leq 0.05)$. Take 2015 as an example, LAI of N2 increased by $53 \%(P \leq 0.05)$ and $30 \%(P \leq 0.05)$ compared with N0 and N1 at R1. During the period from V6 to R3, N2 and N3 did not differ $(P>0.05)$. At R6, LAI of N3 increased by $23 \%$ $(P \leq 0.05)$ compared with N2. LAI decreased significantly by $37 \%$ for N0, 32\% for N1, 27\% for N2 and 13\% for N3, respectively, from R3 to R6. The trend in 2016 was similar to 2015 (the effect of interaction of treatment and year was not significant, $P>0.05$ ).

\section{Chlorophyll SPAD Value}

Chlorophyll SPAD value increased significantly $(P \leq 0.01)$ with $\mathrm{N}$ rate (Figure 3). In 2015, chlorophyll SPAD value of N2 was $43 \%(P \leq 0.05)$ and $17 \%(P \leq 0.05)$ higher than that of N0 and $\mathrm{N} 1$ at V6, and N2 and N3 did not differ $(P>0.05)$. At V12, there was no significant difference among treatments, except N0. From R1 to R3, chlorophyll SPAD value was basically stable. At R6, chlorophyll SPAD value of N3 increased by $86 \%(P \leq 0.05)$ compared with N0, 14-19\% $(P \leq 0.05)$ compared with $\mathrm{N} 1$ and $\mathrm{N} 2$, and there was no significant difference between $\mathrm{N} 1$ and $\mathrm{N} 2$

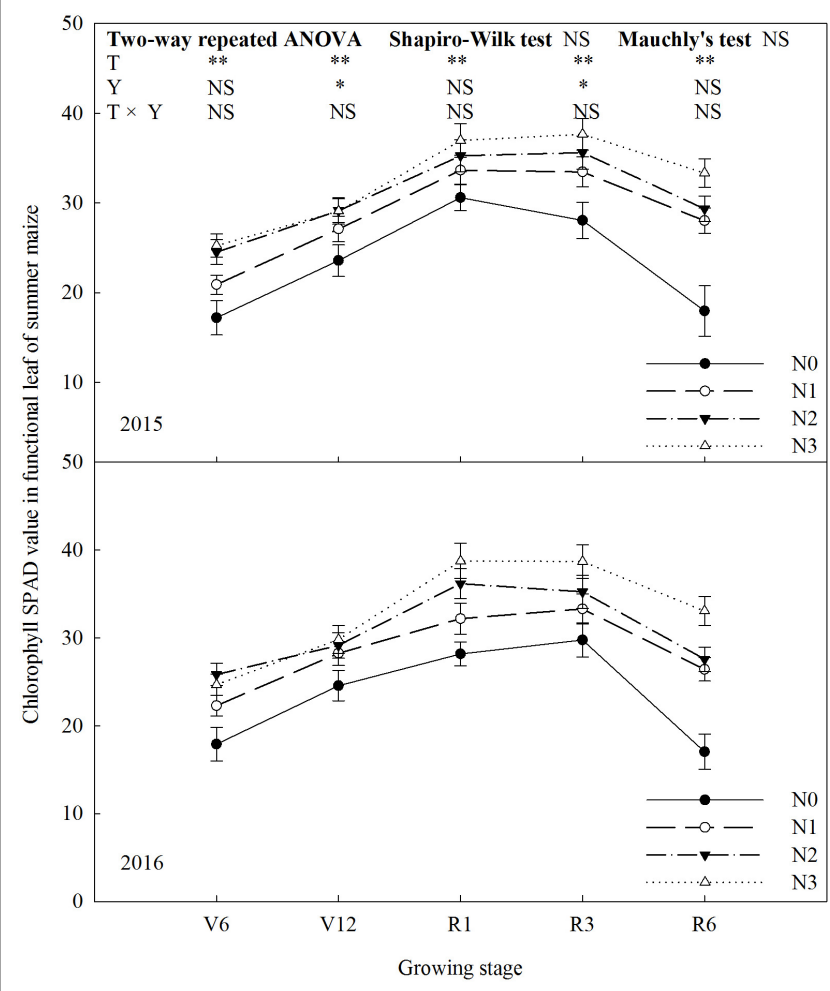

FIGURE 3 | Effect of nitrogen rate on chlorophyll SPAD value in functional leaves of summer maize during growth stages in 2015 and 2016. V6: six-leaf stage, V12: twelve-leaf stage, R1: silking stage, R3: milk stage, R6: physiological maturity stage. Nitrogen applied to maize are $0 \mathrm{~kg} \mathrm{~N} \mathrm{ha}^{-1}$ (NO), $129 \mathrm{~N} \mathrm{ha}^{-1}$ (N1), $185 \mathrm{~kg} \mathrm{~N} \mathrm{ha}^{-1}$ (N2), and $300 \mathrm{~kg} \mathrm{~N} \mathrm{ha}^{-1}$ (N3). Functional leaf: last ligulated leaf at V6, and ear leaf at other stages. Error bars are given as SD. NS, not significant, $P>0.05 .^{*},{ }^{* *}$ Significant at the 0.05 and 0.01 probability level, respectively.

$(P>0.05)$. During the period from $\mathrm{R} 3$ to R6, chlorophyll SPAD value decreased significantly by $40 \%$ for N0, $16 \%$ for N1, $17 \%$ for $\mathrm{N} 2$ and $11 \%$ for $\mathrm{N} 3$. The trends for 2 years were similar $(P>0.05)$.

\section{Dry Matter Weight}

$\mathrm{N}$ rate affected dry matter weight of summer maize significantly (Figure 4). The dry matter weight increased with increase in $\mathrm{N}$ rate up to N2 $(P \leq 0.05)$. N2 and N3 did not differ in dry matter weight $(P>0.05)$. At R1, dry matter weight of $\mathrm{N} 2$ increased by $37 \%(P \leq 0.05)$ and $8 \%(P \leq 0.05)$ compared with N0 and N1, and there was no significant difference between N2 and N3 $(P>0.05)$. At R6, dry matter weight of N2 was $51 \%(P \leq 0.05)$ and $34 \%$ $(P \leq 0.05)$ higher than that of N0 and N1. The results of 2 years did not differ $(P>0.05)$.

\section{Leaf Gas Exchange Parameters}

$\mathrm{N}$ rate affected leaf gas exchange parameters significantly $(P \leq 0.05)$ and the trends of 2 years' results were similar $(P>0.05)$. As shown in Figure 5A, net photosynthetic rate $\left(P_{\mathrm{n}}\right)$ increased $(P \leq 0.05)$ with increase $\mathrm{N}$ rate up to $\mathrm{N} 2$ and decreased $(P \leq 0.05)$ under N3 (except V6). During the period from V6 


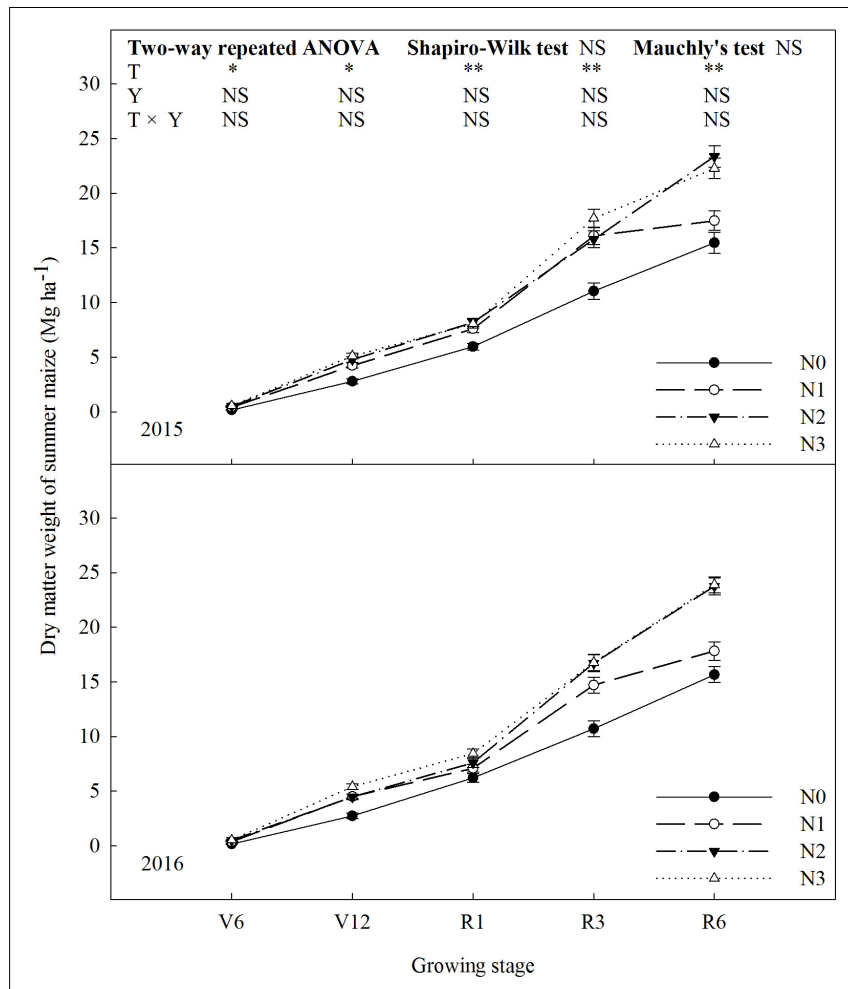

FIGURE 4 | Effect of nitrogen rate on dry matter weight of summer maize during growth stages in 2015 and 2016. V6: six-leaf stage, V12: twelve-leaf stage, R1: silking stage, R3: milk stage, R6: physiological maturity stage. Nitrogen applied to maize are $0 \mathrm{~kg} \mathrm{~N} \mathrm{ha}^{-1}(\mathrm{NO}), 129 \mathrm{~N} \mathrm{ha}^{-1}(\mathrm{~N} 1), 185 \mathrm{~kg} \mathrm{~N}$ $\mathrm{ha}^{-1}$ (N2), and $300 \mathrm{~kg} \mathrm{~N}^{-1}$ (N3). Error bars are given as SD. NS, not significant, $P>0.05 .{ }^{*},{ }^{*}$ Significant at the 0.05 and 0.01 probability level, respectively.

to R3, $P_{\mathrm{n}}$ gradually increased. At V6, $P_{\mathrm{n}}$ of $\mathrm{N} 2$ increased by 113\% $(P \leq 0.05)$ and 36\% $(P \leq 0.05)$ compared with N0 and $\mathrm{N} 1$, respectively. $\mathrm{N} 2$ and $\mathrm{N} 3 \operatorname{did}$ not $\operatorname{differ}(P>0.05)$. At R1, $P_{\mathrm{n}}$ of $\mathrm{N} 2$ increased by $101 \%(P \leq 0.05), 37 \%(P \leq 0.05)$, and $10 \%(P \leq 0.05)$ compared with N0, N1, and N3. The trend at $\mathrm{R} 3$ was accord with that at $\mathrm{R} 1$. Transpiration rate $\left(T_{\mathrm{r}}\right)$ increased with $\mathrm{N}$ rate and decreased with growing stage (Figure 5B). At V6, $T_{\mathrm{r}}$ of N3 was $152 \%(P \leq 0.05), 86 \%(P \leq 0.05)$, and $38 \%$ $(P \leq 0.05)$ higher than that of N0, N1, and N2, respectively. The similar trends occurred at R1 and R3, however, N0 and N1 did not differ $(P>0.05)$. Stomatal conductance $\left(G_{\mathrm{s}}\right)$ increased with $\mathrm{N}$ rate, however, $\mathrm{N} 0$ and $\mathrm{N} 1$ did not differ at $\mathrm{R} 1$ and $\mathrm{N} 2$ and N3 did not differ at R3 (Figure 6A). As shown in Figure 6B, $\mathrm{N}$ fertilization reduced intercellular $\mathrm{CO}_{2}$ concentration $\left(C_{\mathrm{i}}\right)$ significantly. $C_{\mathrm{i}}$ increased and then decreased during growth stages. $C_{\mathrm{i}}$ at R1was significantly higher than that at other times. $C_{\mathrm{i}}$ of N0 was the highest $(P \leq 0.05)$, and N2 and N3 did not differ $(P>0.05)$.

\section{Chlorophyll Fluorescence Parameters}

$\mathrm{N}$ rate affected the maximal quantum efficiency of PSII $\left(F_{\mathrm{v}} / F_{\mathrm{m}}\right)$ and the quantum efficiency of PSII ( $\left.\Phi_{\text {PSII }}\right)$ significantly (Figure 7$) . F_{\mathrm{V}} / F_{\mathrm{m}}$ and $\Phi_{\mathrm{PSII}}$ increased during growth stages and increased significantly when $\mathrm{N}$ rate increased up to $\mathrm{N} 2(P \leq 0.05)$ and the trends of 2 years' results were similar $(P>0.05) . F_{\mathrm{V}} / F_{\mathrm{m}}$ between N2 and N3 did not differ at R3 in $2016(P>0.05)$, and $\Phi_{\text {PSII }}$ between N2 and N3 did not at V6 $(P>0.05)$. In addition to above, $F_{\mathrm{V}} / F_{\mathrm{m}}$ and $\Phi_{\mathrm{PSII}}$ of $\mathrm{N} 3$ were significantly lower than that of N2 $(P \leq 0.05)$. Take 2015 as an example, $F_{\mathrm{v}} / F_{\mathrm{m}}$ of $\mathrm{N} 2$ increased by $4.3 \%(P \leq 0.05), 2.9 \%(P \leq 0.05)$, and $4.3 \%(P \leq 0.05)$ at V6; $13.2 \%(P \leq 0.05), 6.9 \%(P \leq 0.05)$, and $4.1 \%(P \leq 0.05)$ at $\mathrm{R} 1 ; 12.0 \%(P \leq 0.05), 6.3 \%(P \leq 0.05)$, and $3.7 \%(P \leq 0.05)$ at R3 compared with $\mathrm{N} 0, \mathrm{~N} 1$, and $\mathrm{N} 3$, respectively. $\Phi_{\mathrm{PSII}}$ of N2 increased by $7.4 \%(P \leq 0.05), 10.9 \%(P \leq 0.05)$, and $5.2 \%$ $(P>0.05)$ at V6; $20.8 \%(P \leq 0.05), 10.3 \%(P \leq 0.05)$, and $6.7 \%(P \leq 0.05)$ at $\mathrm{R} 1 ; 20.0 \%(P \leq 0.05), 14.7 \%(P \leq 0.05)$, and $6.8 \%(P \leq 0.05)$ at R3 compared with N0, N1, and N3, respectively.

\section{Chloroplast Form and Configuration}

As show in Table 4, the number of chloroplasts per mesophyll cell of N1 and N1 decreased by $33 \%(P \leq 0.05)$ and $9 \%(P \leq 0.05)$ at V6; 38\% $(P \leq 0.05)$ and $20 \%(P \leq 0.05)$ at $\mathrm{R} 1 ; 27 \%(P \leq 0.05)$ and $10 \%(P \leq 0.05)$ at R3 compared with N2, respectively. N2 and N3 did not differ $(P>0.05)$. The external of chloroplasts changed from long and oval to elliptical, almost circular or irregular under N0 and N1 (Figures 8B,E). Chloroplast morphology was the most damaged under N0 occurred at R3 (Figure 8C), and the damage degree increased with growing stage. The length of chloroplasts for N0 and N1 decreased by $14-33 \%(P \leq 0.05)$ and $8-22 \%$ $(P \leq 0.05)$, and width increased by $17-29 \%(P \leq 0.05)$ and $15-$ $18 \%(P \leq 0.05)$, respectively, compared with N2. N2 and N3 did not differ in chloroplast size $(P>0.05)$, except length for N3 was higher $(P \leq 0.05)$ at V6.

\section{Chloroplast Ultrastructure}

As for the N2 and N3 plants, chloroplasts had a complete external envelope and clear boundary, and the thylakoid systems were well-developed (Figures 8G-L). The lamella structure pile folds were in order, and both gram lamella and stroma lamellae were arranged compactly and clearly (Figures 9G-I). Chloroplasts of N0 and N1 were partially damaged, the external capsule gram lamellae were fuzzy and disordered, the interlayer gap became larger, and multivesicular bodies were occasionally found and most chloroplasts were similarly round and showed external envelope degradation at R3 (Figures 8A-F, 9A-F). The chloroplast internal structure was deteriorated, and the numbers of gram lamellae were reduced significantly $(P \leq 0.05)$ to varying degrees. In N0 and N1 treatments, the gram and substrate lamellae were not clearly differentiated, the number of multivesicular body was increased, and individual chloroplasts disintegrated. In N3 treatment, gram and gram lamellae were still well developed and exhibited only partial adventitia fractures. However, the lamellar structure was arranged loosely, and cracks among lamellae were evident and the gram lamellae gradually became twisted (Figures 9J-L). The negative effects varied with growth stage. As shown in Table 4, the number of lamellae per grana for $\mathrm{N} 2$ increased by $56-515 \%(P \leq 0.05)$ and $20-74 \%$ $(P \leq 0.05)$ compared with $\mathrm{N} 0$ and N1, respectively. At V6, the number of grana per chloroplast for N2 was higher $(P \leq 0.05)$ 

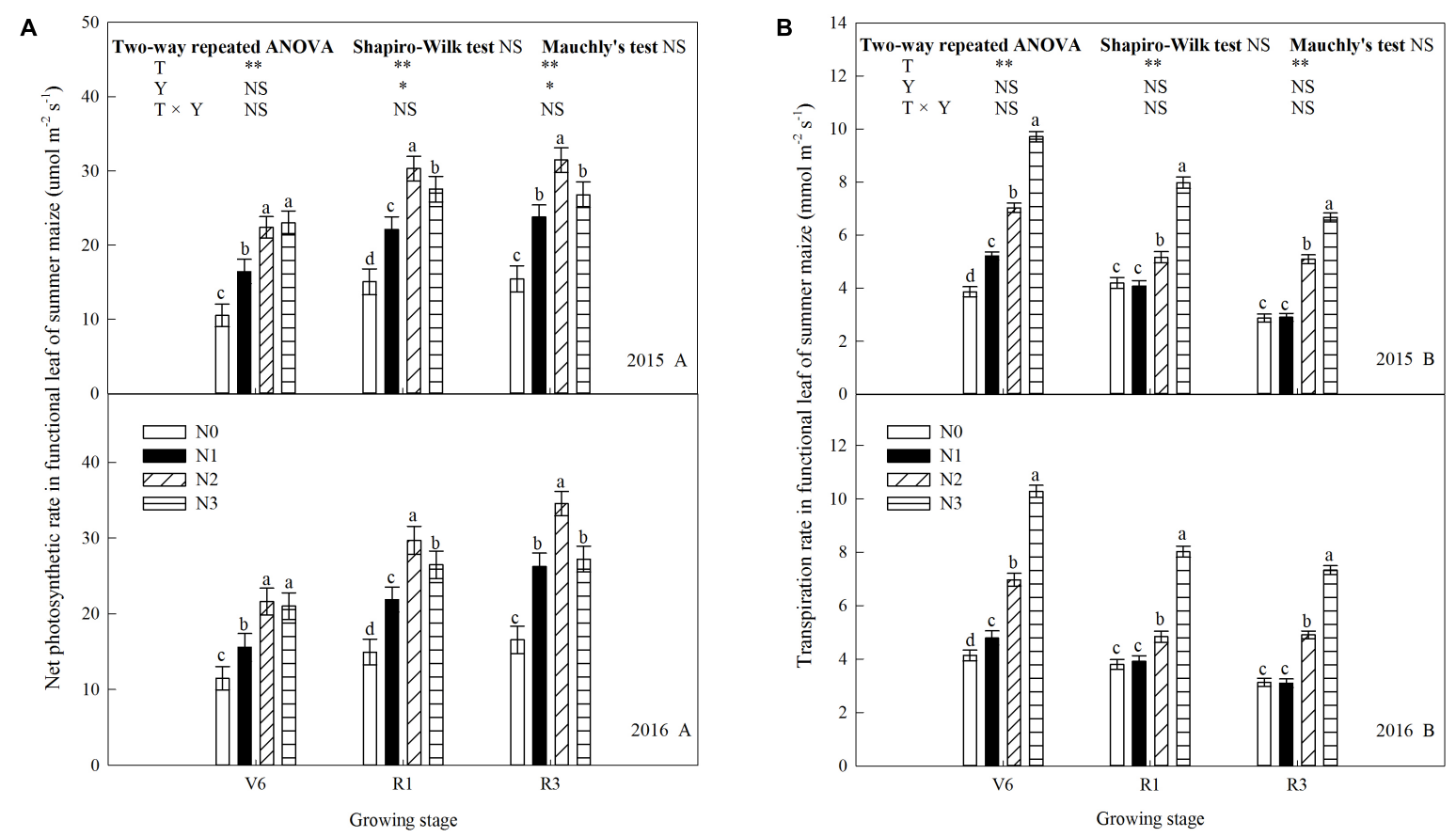

FIGURE 5 | Effect of nitrogen rate on photosynthetic rate $\left(P_{n}\right)$ and transpiration rate $\left(T_{\mathrm{r}}\right)$ in functional leaves of summer maize during growth stages in 2015 and 2016. (A) Photosynthetic rate, (B) transpiration rate. V6: six-leaf stage, R1: silking stage, R3: milk stage. Nitrogen applied to maize are 0 kg N ha-1 (N0), 129 N $\mathrm{ha}^{-1}$ (N1), $185 \mathrm{~kg} \mathrm{~N} \mathrm{ha}^{-1}$ (N2), and $300 \mathrm{~kg} \mathrm{~N} \mathrm{ha}^{-1}$ (N3). Functional leaf: last ligulated leaf at V6, and ear leaf at R1 and R3. Treatments in the same growing stage with different small letters are significantly different at $5 \%$ probability level. Error bars are given as SD. NS, not significant, $P>0.05$. * , * Significant at the 0.05 and 0.01 probability level, respectively.
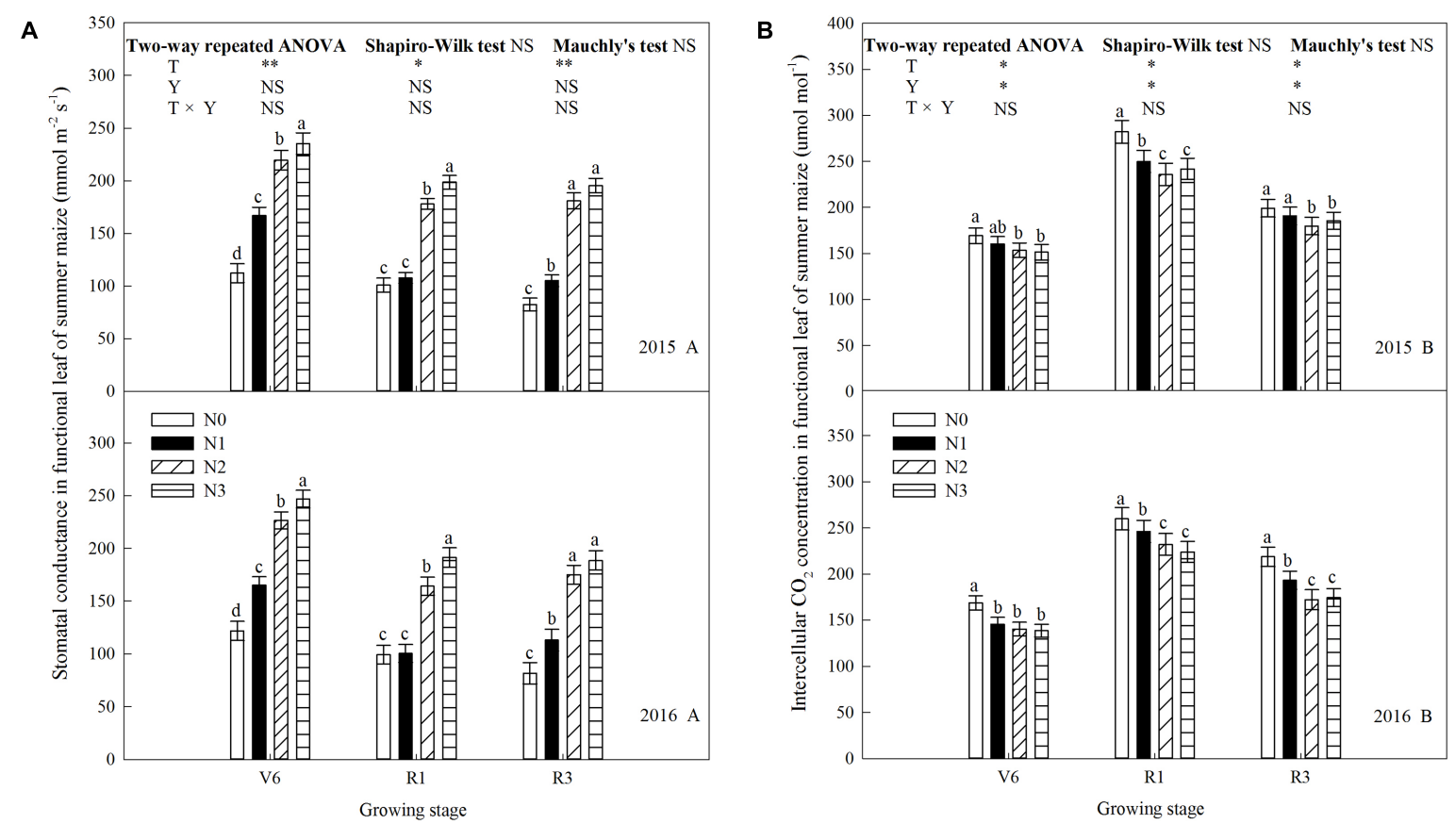

FIGURE 6 | Effect of nitrogen rate on stomatal conductance $\left(G_{\mathrm{S}}\right)$ and intercellular $\mathrm{CO}_{2}$ concentration $\left(C_{\mathrm{i}}\right)$ in functional leaves of summer maize during growth stages in 2015 and 2016. (A) Stomatal conductance, (B) intercellular $\mathrm{CO}_{2}$ concentration. V6: six-leaf stage, R1: silking stage, R3: milk stage. Nitrogen applied to maize are $0 \mathrm{~kg} \mathrm{~N}$ ha ${ }^{-1}$ (N0), $129 \mathrm{~N} \mathrm{ha}^{-1}$ (N1), $185 \mathrm{~kg} \mathrm{~N} \mathrm{ha}^{-1}$ (N2), and $300 \mathrm{~kg} \mathrm{~N}$ ha $^{-1}$ (N3). Functional leaf: last ligulated leaf at V6, and ear leaf at R1 and R3. Treatments in the same growing stage with different small letters are significantly different at $5 \%$ probability level. Error bars are given as SD. NS, not significant, $P>0.05 . *$, **Significant at the 0.05 and 0.01 probability level, respectively. 

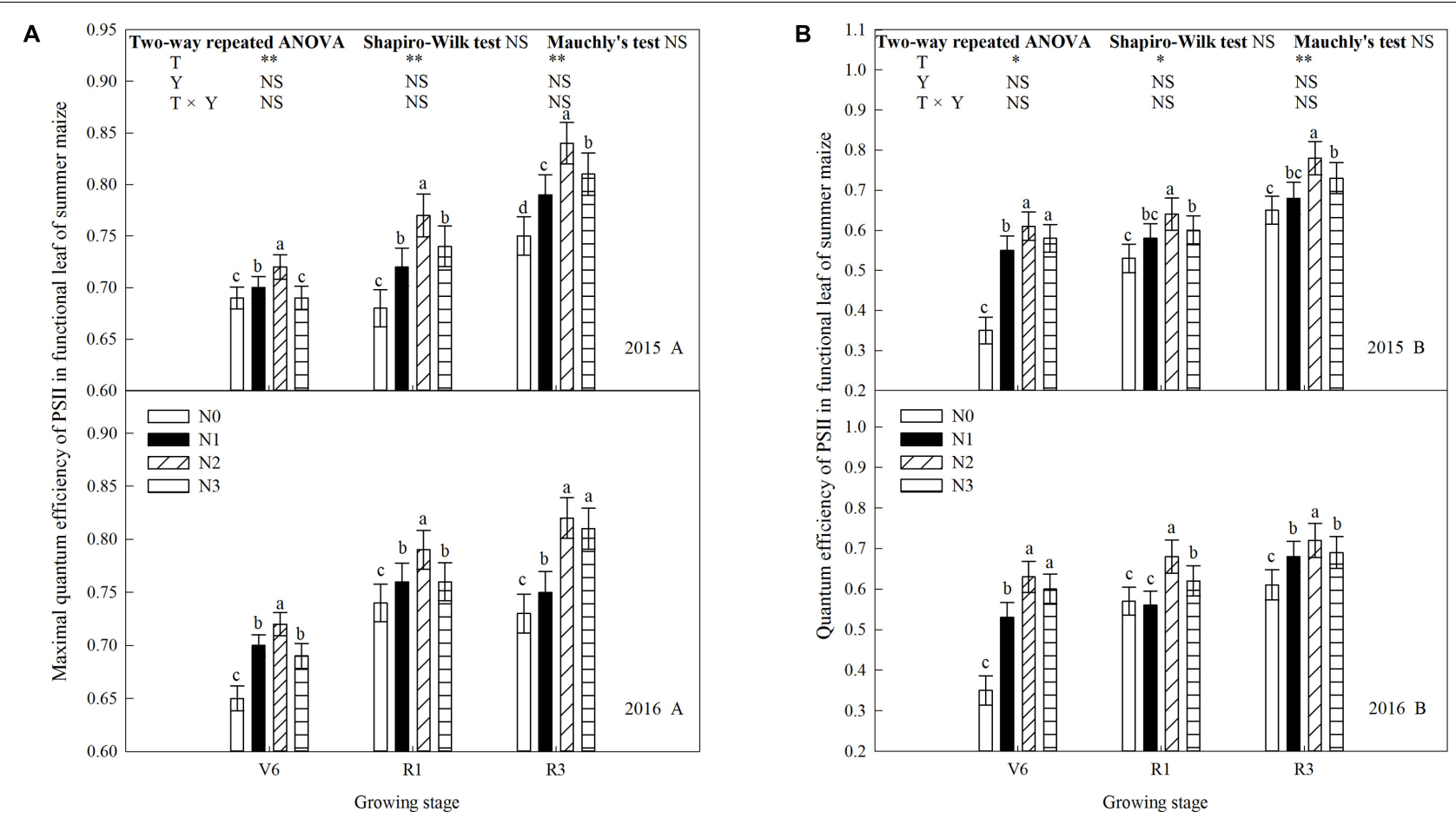

FIGURE 7 | Effect of nitrogen rate on chlorophyll fluorescence in functional leaves of summer maize during growth stages in 2015 and 2016 . (A) Maximal quantum efficiency, (B) quantum efficiency. V6: six-leaf stage, R1: silking stage, R3: milk stage. Nitrogen applied to maize are $0 \mathrm{~kg} \mathrm{~N} \mathrm{ha}^{-1}$ (N0), $129 \mathrm{~N}$ ha ${ }^{-1}$ (N1), $185 \mathrm{~kg} \mathrm{~N}^{-1}$ $\mathrm{ha}^{-1}$ (N2), and $300 \mathrm{~kg} \mathrm{~N}^{-1}$ (N3). Functional leaf: last ligulated leaf at V6, and ear leaf at R1 and R3. Treatments in the same growing stage with different small letters are significantly different at $5 \%$ probability level. Error bars are given as SD. NS, not significant, $P>0.05$. *, ** Significant at the 0.05 and 0.01 probability level, respectively.

than others, however, that for N0 was higher $(P \leq 0.05)$ at R1 and R3. N2 and N3 did not differ $(P>0.05)$, except lamellae number of N3 was less at R3 $(P \leq 0.05)$.

\section{Correlation Analysis Between Photosynthetic Characters and Grain Yield}

According to correlation analysis, there were positive correlation between grain yield and the parameters of photosynthesis and chlorophyll although someone was not significant (Table 5). At V6, chlorophyll SPAD value was significantly correlated with grain yield $(P \leq 0.05)$. At $\mathrm{R} 1, P_{\mathrm{n}}(P \leq 0.05)$ and $\Phi_{\mathrm{PSII}}(P \leq 0.01)$ correlated with grain yield. At R3, LAI, chlorophyll SPAD value and $P_{\mathrm{n}}$ were positively correlated with grain yield $(P \leq 0.05)$ and the correlation between $\Phi_{\mathrm{PSII}}$ and yield was extremely significant $(P \leq 0.01)$. As shown in Table 6, grain yield correlated positively with the number of chloroplast per cell, grana per chloroplast and lamellae per chloroplast although someone was not significant. There were significantly positive correlations between yield and chloroplast number at $\mathrm{R} 1(P \leq 0.05)$ and $\mathrm{R} 3(P \leq 0.01)$. The number of lamellae per grana was significantly correlated with yield at R1 and R3 $(P \leq 0.05)$. The number of lamellae per chloroplast correlated significantly with yield during growth stages $(P \leq 0.05)$. Note that the significant positive correlation between yield and grana number appeared at V6 $(P \leq 0.05)$ and negative correlation appeared at R1 $(P>0.05)$ and R3 $(P \leq 0.05)$.

\section{DISCUSSION}

$\mathrm{N}$ is the necessary element for crop growth and development, and also is the limitation to stable and high grain yield (Uhart and Andrade, 1995; Kamara et al., 2003). In the NCP, local farmers usually applied excessive $\mathrm{N}$ fertilizer, which led to waste of resources and pollution instead of higher yield (Liu et al., 2003). Previous research proved that $185 \mathrm{~kg} \mathrm{~N} \mathrm{ha}^{-1}$ was the appropriate level in this region (Jin et al., 2012). In this study, the average grain yield of N2 increased significantly by 30 and $9 \%$ compared with $\mathrm{N} 0$ and N1, however, N2 and N3 did not differ, which agreed with the previous reports (Lemcoff and Loomis, 1994; Liu et al., 2017). According to yield components, ears per hectare, kernels per ear and TKW had different levels of increase with increase $\mathrm{N}$ rate. There was no significant difference in kernels per ear among N1, N2, and N3, which indicate that kernels per ear is insensitive to $\mathrm{N}$ rate. N0 treatment not only impair grain-filling and kernel development but also lead ear abortion, which are consistent with the previous reports (Monneveux et al., 2005). Note that a lower TKW under N3 appeared in 2016. The reason may be that the excessive $\mathrm{N}$ delay crop maturation and hinder nutrition transport from vegetative organ to reproductive 


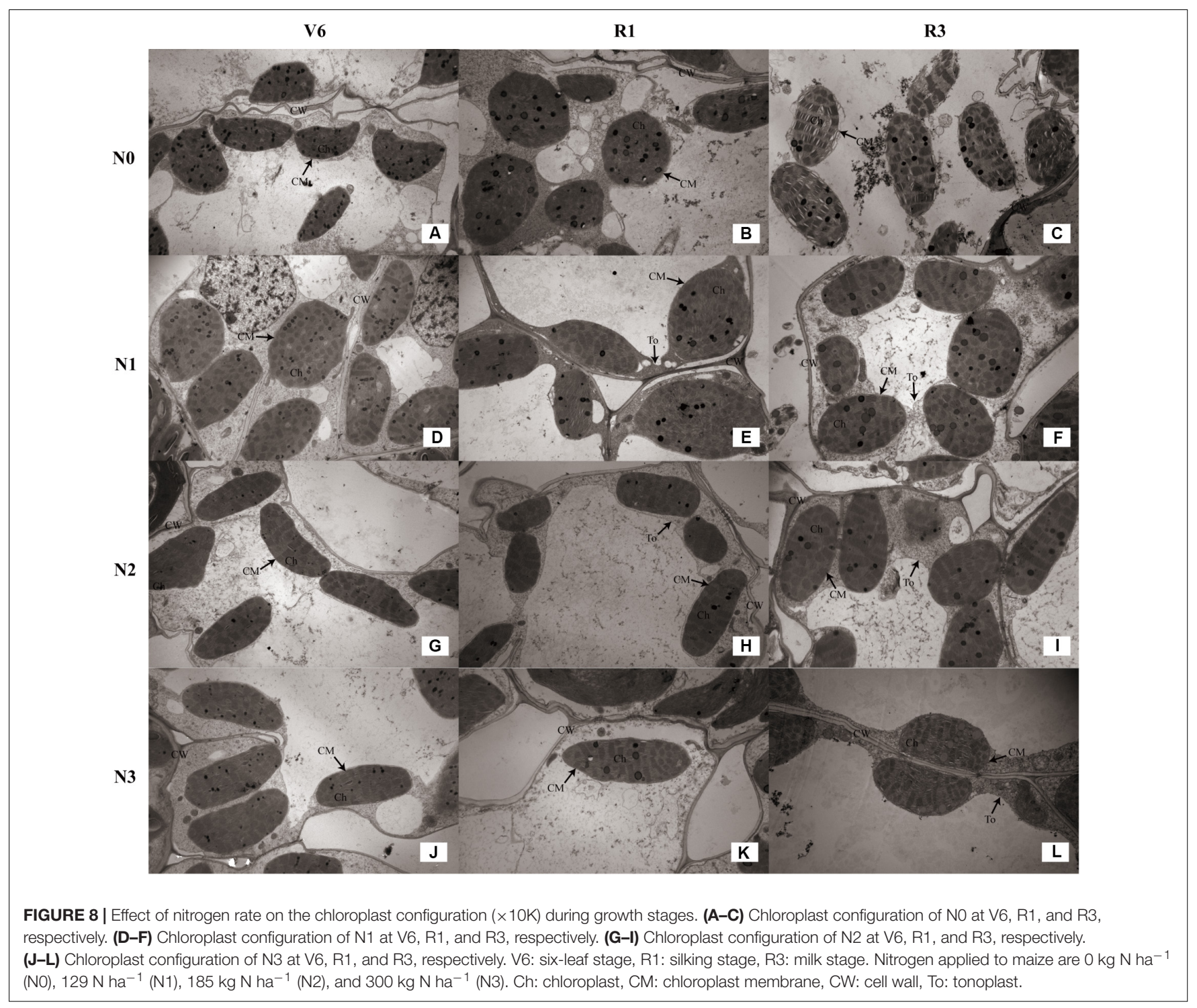

organ at later growing stage (Schröder et al., 2000; Jin et al., 2012). The key to high grain yield of summer maize is to force ears per hectare, kernels per ear and TKW coordinate more.

$\mathrm{N}$ had important effects on photosynthetic characteristics (Sinclair and Horie, 1989; Makino and Osmond, 1991; Sade et al., 2017). LAI reflected the nutritional status and potential photosynthetic area of summer maize (Duncan, 1971; Gitelson et al., 2014). In this study, LAI increased with $\mathrm{N}$ rate, however, $\mathrm{N} 2$ and N3 did not differ, which coincides with the previous study (Liu et al., 2017). The grain yield was significantly and positively correlated with the LAI at R3, that is, it is important for grain yield to maintain a high level of LAI at later growing stage. The chlorophyll SPAD value was used to measure relative chlorophyll content in leaf (Costa et al., 2001; Martínez and Guiamet, 2004). In this study, the more $\mathrm{N}$ fertilizer will help maintain high chlorophyll SPAD value at later growing stage, however, N2 and $\mathrm{N} 3$ did not differ at early growing stage. According to correlation analysis, grain yield was significantly and positively correlated with the chlorophyll SPAD value at V6 and R3. At early growing stage, the higher chlorophyll SPAD value promote the using efficiency of light and the growth and development of vegetative organs. At later growing stage, maintaining higher chlorophyll SPAD value promote photosynthesis which help grain-filling. The great $\mathrm{N}$ state improve gas exchange parameters significantly. In this study, $P_{\mathrm{n}}$ of $\mathrm{N} 2$ increased by $101-113 \%$ and $36-37 \%$ compared with N0 and N1, respectively. $T_{\mathrm{r}}$ and $G_{\mathrm{s}}$ increased, and $C_{\mathrm{i}}$ decreased with $\mathrm{N}$ rate increased up to $\mathrm{N} 2$. According to previous studies (Sadras and Milroy, 1996; Hura et al., 2007; Anjum et al., 2011), N0 and N1 treatments limit photosynthesis resulting from both stomatal limitation (gas exchange between functional leaf and environment is limited) and non-stomatal limitation (carboxylation is impaired, that is, the photosynthetic apparatus are destroyed). In comparison with $\mathrm{N} 2, T_{\mathrm{r}}$ and $G_{\mathrm{s}}$ increased by $31-66 \%$ and $7-17 \%$, respectively, under $\mathrm{N} 3$, that is, the loss of water is higher. The grain yield of summer maize 


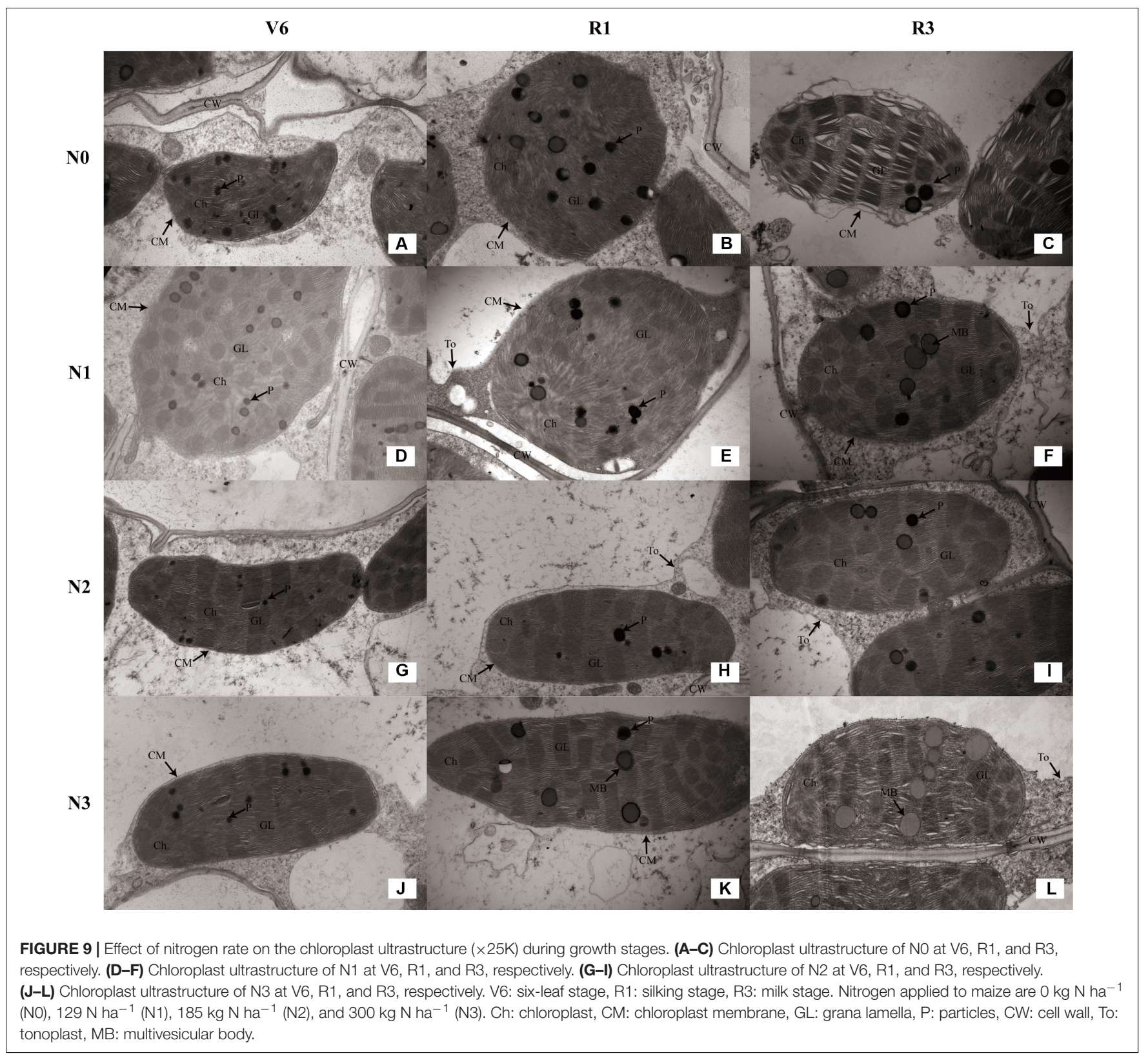

had significantly positive correlation with $P_{\mathrm{n}}$ at R1 and R3. This suggest that one of the keys to high grain yield is increasing photosynthetic rate and extending peak-hours of photosynthesis (Tollenaar and Lee, 2002). $F_{\mathrm{V}} / F_{\mathrm{m}}$ and $\Phi_{\text {PSII }}$ are indicators to evaluate the performance of photosynthesis (Genty et al., 1989; Wagle et al., 2016; Su et al., 2017). In this study, $F_{\mathrm{v}} / F_{\mathrm{m}}$ of N2 increased by $4-13 \%, 3-7 \%$, and $4 \%$, and $\Phi_{\text {PSII }}$ of $\mathrm{N} 2$ increased by $7-21 \%, 10-15 \%$, and $5-7 \%$ compared to N0, N1 and N3, respectively. This indicate that appropriate $\mathrm{N}$ rate improve the performance of PSII. The correlation between grain yield and $F_{\mathrm{V}} / F_{\mathrm{m}}$ did not reach significant level during the growing stages. The grain yield had extremely significant and positive correlation with $\Phi_{\text {PSII }}$ at R1 and R3, which suggest that the performance of PSII have significant effects on grain yield, especially at reproductive growth stage (Lu and Zhang, 2000). The above photosynthetic characteristics affected dry matter weight. During the period from V6 to R6, dry matter weight of N0 was lower than the others and the gap between N0 and N2 enlarged with growing stage, which is consistent with previous research (Binder et al., 2000; Ciampitti and Vyn, 2012).

The photosynthetic characteristics are close to chloroplast configuration and ultrastructure (Giles et al., 1976; Niki et al., 1978). Chloroplast is the main site that produce ROS under stress (Xu et al., 2006). Previous studies indicated that chill stress led to the rupture of chloroplast membrane, and the drought and shade would destroy thylakoid membrane (Giles et al., 1976; Niki et al., 1978; Weston et al., 2000). Normal chloroplast configuration and structure are important 
TABLE 4 | Chloroplast ultrastructure characteristics in mesophyll cells of summer maize last ligulated leaf at six-leaf stage (V6), and ear leaves at silking (R1) and milk stage (R3) as affected by $\mathrm{N}$ rate.

\begin{tabular}{|c|c|c|c|c|c|c|}
\hline \multirow[t]{2}{*}{ Growth stage } & \multirow[t]{2}{*}{ Treatment } & \multirow[t]{2}{*}{ Chloroplast per mesophyll cell } & \multicolumn{2}{|c|}{ Chloroplast size } & \multirow[t]{2}{*}{ Grana per chloroplast } & \multirow[t]{2}{*}{ Lamellae per grana } \\
\hline & & & Length ( $\mu \mathrm{m})$ & Width ( $\mu \mathrm{m})$ & & \\
\hline \multirow[t]{4}{*}{ V6 } & NO & $6.8^{\mathrm{C}}$ & $4.9^{d}$ & $3.3^{\mathrm{a}}$ & $20.1^{c}$ & $16.3^{\mathrm{C}}$ \\
\hline & N1 & $8.3^{b}$ & $5.2^{\mathrm{C}}$ & $3.1^{a}$ & $23.4^{b}$ & $21.1^{\mathrm{b}}$ \\
\hline & $\mathrm{N} 2$ & $10.2^{a}$ & $5.7^{b}$ & $2.7^{\mathrm{b}}$ & $25.3^{a}$ & $25.4^{a}$ \\
\hline & N3 & $9.9^{a}$ & $6.1^{a}$ & $2.7^{\mathrm{b}}$ & $25.7^{a}$ & $25.2^{a}$ \\
\hline \multirow[t]{4}{*}{$\mathrm{R} 1$} & NO & $7.8^{\mathrm{C}}$ & $5.1^{\mathrm{C}}$ & $4.9^{\mathrm{a}}$ & $27.6^{a}$ & $10.4^{\mathrm{c}}$ \\
\hline & N1 & $10.1^{b}$ & $5.9^{b}$ & $4.5^{b}$ & $20.8^{c}$ & $24.7^{b}$ \\
\hline & $\mathrm{N} 2$ & $12.6^{a}$ & $7.6^{\mathrm{a}}$ & $3.8^{\mathrm{c}}$ & $22.4^{b}$ & $30.0^{\mathrm{a}}$ \\
\hline & N3 & $12.5^{\mathrm{a}}$ & $7.8^{\mathrm{a}}$ & $3.9^{c}$ & $22.1^{b}$ & $30.6^{a}$ \\
\hline \multirow[t]{4}{*}{ R3 } & NO & $9.1^{\mathrm{c}}$ & $5.2^{b}$ & $4.8^{a}$ & $28.3^{a}$ & $7.2^{d}$ \\
\hline & $\mathrm{N} 1$ & $11.2^{\mathrm{b}}$ & $5.7^{b}$ & $4.7^{\mathrm{a}}$ & $21.0^{c}$ & $25.5^{c}$ \\
\hline & $\mathrm{N} 2$ & $12.5^{\mathrm{a}}$ & $7.9^{\mathrm{a}}$ & $4.1^{b}$ & $22.1^{b}$ & $44.3^{\mathrm{a}}$ \\
\hline & N3 & $12.7^{a}$ & $7.8^{\mathrm{a}}$ & $4.0^{b}$ & $21.9^{b}$ & $38.1^{b}$ \\
\hline Shapiro-Wilk test & & NS & NS & NS & NS & NS \\
\hline Levene test & & NS & NS & NS & NS & NS \\
\hline \multicolumn{7}{|l|}{ One-way ANOVA } \\
\hline Treatment & & $* *$ & $* *$ & $* *$ & $* *$ & $* *$ \\
\hline
\end{tabular}

Values followed by a different small letter in the same growth stage are significantly different at $P \leq 0.05$ with Duncan's multiple range test. NS, not significant, $P>0.05$. **Significant at the 0.01 probability level. Nitrogen applied to maize are $0 \mathrm{~kg} \mathrm{~N} \mathrm{ha}^{-1}$ (NO), $129 \mathrm{~N} \mathrm{ha}^{-1}$ (N1), $185 \mathrm{~kg} \mathrm{~N} \mathrm{ha-1}^{-1} \mathrm{N2}$ ), and $300 \mathrm{~kg} \mathrm{~N} \mathrm{ha-1} \mathrm{(N3).}$

TABLE 5 | Correlation coefficients between grain yield of summer maize and the parameters of photosynthesis and chlorophyll fluorescence during growth stages (V6: six-leaf stage; R1: silking stage; R3: milk stage).

\begin{tabular}{llll}
\hline Correlation coefficients & \multicolumn{1}{c}{ V6 } & \multicolumn{1}{c}{$\mathbf{R 1}$} & R3 \\
\hline LAl & $0.853^{\mathrm{NS}}$ & $0.917^{\mathrm{NS}}$ & $0.969^{*}$ \\
SPAD & $0.973^{*}$ & $0.939^{\mathrm{NS}}$ & $0.976^{*}$ \\
$P_{\mathrm{n}}$ & $0.898^{\mathrm{NS}}$ & $0.978^{*}$ & $0.981^{*}$ \\
$F_{\mathrm{V}} / F_{\mathrm{m}}$ & $0.806^{\mathrm{NS}}$ & $0.902^{\mathrm{NS}}$ & $0.851^{\mathrm{NS}}$ \\
$\Phi_{\mathrm{PS} \|}$ & $0.825^{\mathrm{NS}}$ & $0.991^{* *}$ & $0.993^{* *}$ \\
\hline
\end{tabular}

NS, not significant, $P>0.05 . *{ }^{*} *$ Significant at the 0.05 and 0.01 probability level, respectively.

TABLE 6 | Correlation coefficients between grain yield of summer maize and chloroplast ultrastructures during growth stages (V6: six-leaf stage; R1: silking stage; R3: milk stage).

\begin{tabular}{llcr}
\hline Correlation coefficients & \multicolumn{1}{c}{ V6 } & R1 & R3 \\
\hline Chloroplast per mesophyll cell & $0.931^{\mathrm{NS}}$ & $0.956^{*}$ & $0.995^{* *}$ \\
Grana per chloroplast & $0.956^{*}$ & $-0.917^{\mathrm{NS}}$ & $-0.962^{*}$ \\
Lamellae per grana & $0.920^{\mathrm{NS}}$ & $0.985^{*}$ & $0.968^{*}$ \\
Lamellae per chloroplast & $0.974^{*}$ & $0.955^{*}$ & $0.962^{*}$
\end{tabular}

NS, not significant, $P>0.05 .{ }^{*}, * *$ Significant at the 0.05 and 0.01 probability level, respectively.

to photosynthesis. In this study, N0 and N1 treatments caused the chloroplast arranged scattered and ultrastructural damage, and membrane of chloroplast and thylakoid had different degrees of injury, meanwhile, lamellae per grana significantly decreased. The structural damage inevitably result in functional disorder manifesting as decreases in chlorophyll SPAD value (Zhang et al., 2009) and parameters of gas exchange and fluorescence
(Giles et al., 1974, 1976). And the damage degree of chloroplast morphology and ultrastructure increased with growing stage, which may result in faster aging at later growing stage compared with those maize under N2 and N3 treatments (Kołodziejek et al., 2003). The result was a reduction in grain yield. N3 treatment led to increase in the number of osmium granule and vesicle, and the gap between lamellae enlarged, which may be the reason for decreases in photosynthetic rate and quantum efficiency (Stirling et al., 1991; Sowiński et al., 2005). The well-developed chloroplast characterized by large grana, more lamellae and compact structure is important for photosynthesis and grain yield.

\section{CONCLUSION}

In this study, $185 \mathrm{~kg} \mathrm{~N} \mathrm{ha}^{-1}$ is the appropriate application rate for grain yield, photosynthesis and chloroplast ultrastructure. The changes in $\mathrm{N}$ rate result in the difference in photosynthetic characteristics and chloroplast ultrastructure of field-grown maize, which is one of the reasons for yield gap between different $\mathrm{N}$ treatments. The leaf area index and chlorophyll SPAD value increase with nitrogen rate, and the gap between treatments is greater in later growing stage. The chloroplasts have a complete external envelope and clear boundary, and the thylakoid systems are well-developed, and lamellae of both gram and stroma are arranged compactly and clearly under N2. N0 $\left(0 \mathrm{~kg} \mathrm{~N} \mathrm{ha}^{-1}\right)$ and $\mathrm{N} 1\left(129 \mathrm{~kg} \mathrm{~N} \mathrm{ha}^{-1}\right)$ treatments result in both stomatal limitation and non-stomatal restriction, and the damage to chloroplast from the inside out. N3 (300 $\mathrm{kg} \mathrm{N} \mathrm{ha}^{-1}$ ) treatment increases the loss of water instead of raising photosynthetic rate, and lead to more loose lamellae structure and greater gap between lamellae. 


\section{AUTHOR CONTRIBUTIONS}

ZL carried out the measurements, data analysis, and drafted the manuscript. JZ designed the experiments. JG, FG, PL, BZ, and JZ made substantial contributions to conception, and critically revised the manuscript.

\section{REFERENCES}

Anjum, S. A., Wang, L. C., Farooq, M., Hussain, M., Xue, L. L., and Zou, C. M. (2011). Brassinolide application improves the drought tolerance in maize through modulation of enzymatic antioxidants and leaf gas exchange. J. Agron. Crop Sci. 197, 177-185. doi: 10.1111/j.1439-037X.2010.00459.x

Bavec, F., and Bavec, M. (2002). Effects of plant population on leaf area index, cob characteristics and grain yield of early maturing maize cultivars (FAO 100-400). Eur. J. Agron. 16, 151-159. doi: 10.1016/S1161-0301(01)00126-5

Binder, D., Sander, D., and Walters, D. (2000). Maize response to time of nitrogen application as affected by level of nitrogen deficiency. Agron. J. 92, 1228-1236. doi: 10.2134/agronj2000.9261228x

Caers, M., Rudelsheim, P., Van Onckelen, H., and Horemans, S. (1985). Effect of heat stress on photosynthetic activity and chloroplast ultrastructure in correlation with endogenous cytokinin concentration in maize seedlings. Plant Cell Physiol. 26, 47-52. doi: 10.1093/oxfordjournals.pcp.a076894

Chotewutmontri, P., and Barkan, A. (2016). Dynamics of chloroplast translation during chloroplast differentiation in maize. PLoS Genet. 12:e1006106. doi: 10.1371/journal.pgen.1006106

Ciampitti, I., and Vyn, T. (2012). Physiological perspectives of changes over time in maize yield dependency on nitrogen uptake and associated nitrogen efficiencies: a review. Field Crops Res. 133, 48-67. doi: 10.1016/j.fcr.2012.03.008

Combe, L. (2005). Nouvelle méthode de suivi au champ de la sénescence des feuilles de maïs. Can. J. Bot. 83, 941-953. doi: 10.1139/B05-043

Costa, C., Dwyer, L., Dutilleul, P., Stewart, D., Ma, B., and Smith, D. (2001). Interrelationships of applied nitrogen, SPAD, and yield of leafy and non-leafy maize genotypes. J. Plant Nutr. 24, 1173-1194. doi: 10.1081/PLN-100106974

Cui, X., Chen, X., and Zhang, F. (2010). Current nitrogen management status and measures to improve the intensive wheat-maize system in China. Ambio 39, 376-384. doi: 10.1007/s13280-010-0076-6

Duncan, W. (1971). Leaf angles, leaf area, and canopy photosynthesis. Crop Sci. 11, 482-485. doi: 10.2135/cropsci1971.0011183X001100040006x

Escobar-Gutiérrez, A. J., and Combe, L. (2012). Senescence in field-grown maize: from flowering to harvest. Field Crops Res. 134, 47-58. doi: 10.1016/j.fcr.2012. 04.013

Fan, M., Shen, J., Yuan, L., Jiang, R., Chen, X., Davies, W. J., et al. (2012). Improving crop productivity and resource use efficiency to ensure food security and environmental quality in China. J. Exp. Bot. 63, 13-24. doi: 10.1093/jxb/ err248

Fang, Q., Yu, Q., Wang, E., Chen, Y., Zhang, G., Wang, J., et al. (2006). Soil nitrate accumulation, leaching and crop nitrogen use as influenced by fertilization and irrigation in an intensive wheat-maize double cropping system in the North China Plain. Plant Soil 284, 335-350. doi: 10.1007/s11104-0060055-7

Fromm, J., and Fei, H. (1998). Electrical signaling and gas exchange in maize plants of drying soil. Plant Sci. 132, 203-213. doi: 10.1016/S0168-9452(98)00010-7

Gb/T 29890-2013 (2013). Technical criterion for grain and oil-seeds storage. Beijing: Standards Press of China.

Genty, B., Briantais, J., and Baker, N. (1989). The relationship between the quantum yields of photosynthetic elec-tron transport and photo-chemical quenching of chlorophyll fluorescence. Biochim. Biophys. Acta 990, 87-92. doi: 10.1016/ S0304-4165(89)80016-9

Giles, K., Beardsell, M., and Cohen, D. (1974). Cellular and ultrastructural changes in mesophyll and bundle sheath cells of maize in response to water stress. Plant Physiol. 54, 208-212. doi: 10.1104/pp.54.2.208

Giles, K., Cohen, D., and Beardsell, M. (1976). Effects of water stress on the ultrastructure of leaf cells of Sorghum bicolor. Plant Physiol. 57, 11-14. doi: $10.1104 /$ pp.57.1.11

\section{FUNDING}

We are grateful for grants from National Basic Research Program of China (973, Program: 2015CB150404), National Modern Agricultural Technology \& Industry System (CARS-02-18), and Funds of Shandong "Double Tops" Program (SYL2017YSTD02).

Gitelson, A., Peng, Y., Arkebauer, T., and Schepers, J. (2014). Relationships between gross primary production, green LAI, and canopy chlorophyll content in maize: implications for remote sensing of primary production. Remote Sens. Environ. 144, 65-72. doi: 10.1016/j.rse.2014.01.004

Hall, J., Barr, R., Al-Abbas, A., and Crane, F. (1972). The ultrastructure of chloroplasts in mineral-deficient maize leaves. Plant Physiol. 50, 404-409. doi: $10.1104 /$ pp.50.3.404

Harel, E., Lea, P., and Miflin, B. (1977). The localisation of enzymes of nitrogen assimilation in maize leaves and their activities during greening. Planta 134, 195-200. doi: 10.1007/BF00384971

Hura, T., Hura, K., Grzesiak, M., and Rzepka, A. (2007). Effect of long-term drought stress on leaf gas exchange and fluorescence parameters in C3 and C4 plants. Acta Physiol. Plant. 29:103. doi: 10.1007/s11738-006-0013-2

Jin, L., Cui, H., Li, B., Zhang, J., Dong, S., and Liu, P. (2012). Effects of integrated agronomic management practices on yield and nitrogen efficiency of summer maize in North China. Field Crops Res. 134, 30-35. doi: 10.1016/j.fcr.2012. 04.008

Kamara, A., Kling, J., Menkir, A., and Ibikunle, O. (2003). Agronomic performance of maize (Zea mays L.) breeding lines derived from a low nitrogen maize population. J. Agr. Sci. 141, 221-230. doi: 10.1017/S0021859603003514

Kołodziejek, I., Kozioł, J., Wałęza, M., and Mostowska, A. (2003). Ultrastructure of mesophyll cells and pigment content in senescing leaves of maize and barley. J. Plant Growth Regul. 22, 217-227. doi: 10.1007/s00344-002-0024-1

Kong, L., Xie, Y., Hu, L., Si, J., and Wang, Z. (2017). Excessive nitrogen application dampens antioxidant capacity and grain filling in wheat as revealed by metabolic and physiological analyses. Sci. Rep. 7:43363. doi: 10.1038/srep43363

Kratsch, H., and Wise, R. (2000). The ultrastructure of chilling stress. Plant Cell Environ. 23, 337-350. doi: 10.1046/j.1365-3040.2000.00560.x

Lemcoff, J., and Loomis, R. (1994). Nitrogen and density influences on silk emergence, endosperm development, and grain yield in maize (Zea mays L.). Field Crops Res. 38, 63-72. doi: 10.1016/0378-4290(94)90001-9

Liu, X., Ju, X., Zhang, F., Pan, J., and Christie, P. (2003). Nitrogen dynamics and budgets in a winter wheat-maize cropping system in the North China Plain. Field Crops Res. 83, 111-124. doi: 10.1016/S0378-4290(03)00068-6

Liu, Z., Zhu, K., Dong, S., Liu, P., Zhao, B., and Zhang, J. (2017). Effects of integrated agronomic practices management on root growth and development of summer maize. Eur. J. Agron. 84, 140-151. doi: 10.1016/j.eja.2016.12.006

Lu, C., and Zhang, J. (2000). Photosynthetic CO2 assimilation, chlorophyll fluorescence and photoinhibition as affected by nitrogen deficiency in maize plants. Plant Sci. 151, 135-143. doi: 10.1016/S0168-9452(99) 00207-1

Majeran, W., Zybailov, B., Ytterberg, A., Dunsmore, J., Sun, Q., and van Wijk, K. (2008). Consequences of C4 differentiation for chloroplast membrane proteomes in maize mesophyll and bundle sheath cells. Mol. Cell. Proteomics 7, 1609-1638. doi: 10.1074/mcp.M800016-MCP200

Makino, A., and Osmond, B. (1991). Effects of nitrogen nutrition on nitrogen partitioning between chloroplasts and mitochondria in pea and wheat. Plant Physiol. 96, 355-362. doi: 10.1104/pp.96.2.355

Martínez, D., and Guiamet, J. (2004). Distortion of the SPAD 502 chlorophyll meter readings by changes in irradiance and leaf water status. Agronomie 24, 41-46. doi: 10.1051/agro:2003060

Monneveux, P., Zaidi, P., and Sanchez, C. (2005). Population density and low nitrogen affects yield-associated traits in tropical maize. Crop Sci. 45, 535-545. doi: 10.2135/cropsci2005.0535

Niki, T., Yoshida, S., and Sakai, A. (1978). Studies on chilling injury in plant cells I. Ultrastructural changes associated with chilling injury in callus tissues of Cornus stolonifera. Plant Cell Physiol. 19, 139-148. doi: 10.1093/oxfordjournals. pcp.a075568 
Nissanka, S. P., Dixon, M. A., and Tollenaar, M. (1997). Canopy gas exchange response to moisture stress in old and new maize hybrid. Crop Sci. 37, 172-181. doi: 10.2135/cropsci1997.0011183X003700010030x

Plénet, D., and Lemaire, G. (1999). Relationships between dynamics of nitrogen uptake and dry matter accumulation in maize crops. Determination of critical N concentration. Plant Soil 216, 65-82. doi: 10.1023/A:1004783431055

Qi, W., Liu, H., Liu, P., Dong, S., Zhao, B., So, H., et al. (2012). Morphological and physiological characteristics of corn (Zea mays L.) roots from cultivars with different yield potentials. Eur. J. Agron. 38, 54-63. doi: 10.1016/j.eja.2011.12.003

Rajcan, I., and Tollenaar, M. (1999). Source: sink ratio and leaf senescence in maize:: I. Dry matter accumulation and partitioning during grain filling. Field Crops Res. 60, 245-253. doi: 10.1016/S0378-4290(98)00142-7

Richardson, A. D., Duigan, S. P., and Berlyn, G. P. (2002). An evaluation of noninvasive methods to estimate foliar chlorophyll content. New Phytol. 153, 185-194. doi: 10.1046/j.0028-646X.2001.00289.x

Ristic, Z., and Cass, D. (1992). Chloroplast structure after water and hightemperature stress in two lines of maize that differ in endogenous levels of abscisic acid. Int. J. Plant Sci. 153, 186-196. doi: 10.1086/297021

Sade, N., Umnajkitikorn, K., Rubio Wilhelmi, M., Wright, M., Wang, S., and Blumwald, E. (2017). Delaying chloroplast turnover increases water-deficit stress tolerance through the enhancement of nitrogen assimilation in rice. J. Exp. Bot. 69, 867-878. doi: 10.1093/jxb/erx247

Sadras, V. O., and Milroy, S. P. (1996). Soil-water thresholds for the responses of leaf expansion and gas exchange: a review. Field Crops Res. 47, 253-266. doi: 10.1016/0378-4290(96)00014-7

Salesse-Smith, C., Sharwood, R., Sakamoto, W., and Stern, D. (2017). The Rubisco chaperone BSD2 may regulate chloroplast coverage in maize bundle sheath cells. Plant Physiol. 175, 1624-1633. doi: 10.1104/pp.17.0134

Scheuermann, R., Biehler, K., Stuhlfauth, T., and Fock, H. P. (1991). Simultaneous gas exchange and fluorescence measurements indicate differences in the response of sunflower, bean and maize to water stress. Photosynth. Res. 27, 189-197. doi: 10.1007/BF00035840

Schröder, J. J., Neeteson, J. J., Oenema, O., and Struik, P. C. (2000). Does the crop or the soil indicate how to save nitrogen in maize production?: Reviewing the state of the art. Field Crops Res. 66, 151-164. doi: 10.1016/S0378-4290(00) 00072-1

Shao, R., Xin, L., Zheng, H., Li, L., Ran, W., Mao, J., et al. (2016). Changes in chloroplast ultrastructure in leaves of drought-stressed maize inbred lines. Photosynthetica 54, 74-80. doi: 10.1007/s11099-015-0158-6

Sinclair, T., and Horie, T. (1989). Leaf nitrogen, photosynthesis, and crop radiation use efficiency: a review. Crop Sci. 29, 90-98. doi: 10.2135/cropsci1989. 0011183X002900010023x

Slack, C., Hatch, M., and Goodchild, D. (1969). Distribution of enzymes in mesophyll and parenchyma-sheath chloroplasts of maize leaves in relation to the C4-dicarboxylic acid pathway of photosynthesis. Biochem. J. 114, 489-498. doi: 10.1042/bj1140489

Sowiński, P., Rudzińska-Langwald, A., Adamczyk, J., Kubica, I., and Fronk, J. (2005). Recovery of maize seedling growth, development and photosynthetic efficiency after initial growth at low temperature. J. Plant Physiol. 162, 67-80. doi: 10.1016/j.jplph.2004.03.006

Stirling, C. M., Nie, G. Y., Aguilera, C., Nugawela, A., Long, S. P., and Baker, N. R. (1991). Photosynthetic productivity of an immature maize crop: changes in quantum yield of $\mathrm{CO} 2$ assimilation, conversion efficiency and thylakoid proteins. Plant Cell Environ. 14, 947-954. doi: 10.1111/j.1365-3040.1991. tb00964.x

Su, W., Sun, L., Wu, R., Ma, Y., Wang, H., Xu, H., et al. (2017). Effect of imazapic residues on photosynthetic traits and chlorophyll fluorescence of maize seedlings. Photosynthetica 55, 294-300. doi: 10.1007/s11099-016-0641-3
Tilman, D., Balzer, C., Hill, J., and Befort, B. L. (2011). Global food demand and the sustainable intensification of agriculture. P. Natl. Acad. Sci. U.S.A. 108, 20260-20264. doi: 10.1073/pnas.1116437108

Tollenaar, M., and Lee, E. A. (2002). Yield potential, yield stability and stress tolerance in maize. Field Crops Res. 75, 161-169.

Tóth, V., Mészáros, I., Veres, S., and Nagy, J. (2002). Effects of the available nitrogen on the photosynthetic activity and xanthophyll cycle pool of maize in field. J. Plant Physiol. 159, 627-634. doi: 10.1078/0176-1617-0640

Uhart, S., and Andrade, F. (1995). Nitrogen defeciency in maize: I. Effects on crop growth, development, dry matter partitioning, and kernel set. Crop Sci. 35, 1376-1383. doi: 10.2135/cropsci1995.0011183X003500050020x

Wagle, P., Zhang, Y., Jin, C., and Xiao, X. (2016). Comparison of solar-induced chlorophyll fluorescence, light-use efficiency, and process-based GPP models in maize. Ecol. Appl. 26, 1211-1222. doi: 10.1890/15-1434

Wang, H., and Jin, J. (2005). Photosynthetic rate, chlorophyll fluorescence parameters, and lipid peroxidation of maize leaves as affected by zinc deficiency. Photosynthetica 43, 591-596. doi: 10.1007/s11099-005-0092-0

Wang, H., Liu, R., and Jin, J. (2009). Effects of zinc and soil moisture on photosynthetic rate and chlorophyll fluorescence parameters of maize. Biol. Plantarum 53, 191-194. doi: 10.1007/s10535-009-0033-z

Weston, E., Thorogood, K., Vinti, G., and López-Juez, E. (2000). Light quantity controls leaf-cell and chloroplast development in Arabidopsis thaliana wild type and blue-light-perception mutants. Planta 211, 807-815. doi: 10.1007/ s004250000392

Wilhelm, W. W., Ruwe, K., and Schlemmer, M. R. (2000). Comparison of three leaf area index meters in a corn canopy. Crop Sci. 40, 1179-1183. doi: 10.2135/ cropsci2000.4041179x

Xu, S., Li, J., Zhang, X., Wei, H., and Cui, L. (2006). Effects of heat acclimation pretreatment on changes of membrane lipid peroxidation, antioxidant metabolites, and ultrastructure of chloroplasts in two cool-season turfgrass species under heat stress. Environ. Exp. Bot. 56, 274-285. doi: 10.1016/j. envexpbot.2005.03.002

Zhang, J., Blackmer, A. M., and Blackmer, T. M. (2009). Reliability of chlorophyll meter measurements prior to corn silking as affected by the leaf change problem. Commun. Soil Sci. Plant Anal. 40, 2087-2093. doi: 10.1080/ 00103620902960609

Zhang, X., Xu, M., Liu, J., Sun, N., Wang, B., and Wu, L. (2016). Greenhouse gas emissions and stocks of soil carbon and nitrogen from a 20-year fertilised wheat-maize intercropping system: a model approach. J. Environ. Manage. 167, 105-114. doi: 10.1016/j.jenvman.2015.11.014

Zhao, R., Chen, X., Zhang, F., Zhang, H., Schroder, J., and Römheld, V. (2006). Fertilization and nitrogen balance in a wheat-maize rotation system in North China. Agron. J. 98, 938-945. doi: 10.2134/agronj2005.0157

Zhu, K., Jin, L., Dong, S., Zhao, B., Liu, P., and Zhang, J. (2014). Effects of integrated agronomic practices on leaf senescence physiological characteristics of summer maize. Sci. Agr. Sin. 47, 2949-2959. doi: 10.3864/j.issn.0578-1752.2014.15.005

Conflict of Interest Statement: The authors declare that the research was conducted in the absence of any commercial or financial relationships that could be construed as a potential conflict of interest.

Copyright (c) 2018 Liu, Gao, Gao, Liu, Zhao and Zhang. This is an open-access article distributed under the terms of the Creative Commons Attribution License (CC BY). The use, distribution or reproduction in other forums is permitted, provided the original author(s) and the copyright owner are credited and that the original publication in this journal is cited, in accordance with accepted academic practice. No use, distribution or reproduction is permitted which does not comply with these terms. 